Review

\title{
Potential of Fatty Acid Amide Hydrolase (FAAH), Monoacylglycerol Lipase (MAGL), and Diacylglycerol Lipase (DAGL) Enzymes as Targets for Obesity Treatment: A Narrative Review
}

 \\ 1 Translational Addiction Research Laboratory, Campbell Family Mental Health Institute, Centre for Addiction \\ and Mental Health, 33 Ursula Franklin Street, Toronto, ON M5S 2S1, Canada; \\ matt.zhou@mail.utoronto.ca (X.M.M.Z.); zoe.bourgault@camh.ca (Z.B.); Bernard.lefoll@camh.ca (B.L.F.) \\ 2 Department of Pharmacology and Toxicology, Faculty of Medicine, University of Toronto, 27 King's \\ College Circle, Toronto, ON M5S 3H7, Canada \\ 3 Addictions Division, Centre for Addiction and Mental Health, 100 Stokes Street, \\ Toronto, ON M6J 1H4, Canada \\ 4 Department of Psychiatry, Faculty of Medicine, University of Toronto, 250 College Street, \\ Toronto, ON M5T 1R8, Canada \\ check for \\ updates \\ Citation: Matheson, J.; Zhou, \\ X.M.M.; Bourgault, Z.; Le Foll, B. \\ Potential of Fatty Acid Amide \\ 5 Institute of Medical Sciences, University of Toronto, 1 King's College Circle, Room 2374, \\ Toronto, ON M5S 1A8, Canada \\ 6 Department of Family and Community Medicine, University of Toronto, 500 University Avenue, 5th Floor, \\ Toronto, ON M5G 1V7, Canada \\ * Correspondence: justin.matheson@camh.ca
} Hydrolase (FAAH), Monoacylglycerol Lipase (MAGL), and Diacylglycerol Lipase (DAGL) Enzymes as Targets for Obesity Treatment: A Narrative Review. Pharmaceuticals 2021, 14, 1316. https://doi.org/10.3390/ph14121316

Academic Editors:

Magdalena Kotańska, Amélia Pilar Rauter, Małgorzata Szafarz and Monika Kubacka

Received: 9 November 2021 Accepted: 14 December 2021 Published: 17 December 2021

Publisher's Note: MDPI stays neutral with regard to jurisdictional claims in published maps and institutional affiliations.

Copyright: (c) 2021 by the authors. Licensee MDPI, Basel, Switzerland. This article is an open access article distributed under the terms and conditions of the Creative Commons Attribution (CC BY) license (https:// creativecommons.org/licenses/by/ $4.0 /)$.
Abstract: The endocannabinoid system (ECS) plays an integral role in maintaining metabolic homeostasis and may affect hunger, caloric intake, and nutrient absorption. Obesity has been associated with higher levels of the endogenous cannabinoid transmitters (endocannabinoids). Therefore, the ECS is an important target in obesity treatment. Modulating the enzymes that synthesize and degrade endocannabinoids, namely fatty acid amide hydrolase (FAAH), monoacylglycerol lipase (MAGL), and diacylglycerol lipase (DAGL), may be a promising strategy to treat obesity. This review aims to synthesize all studies investigating pharmacological or genetic manipulation of FAAH, MAGL, or DAGL enzymes in association with obesity-related measures. Pharmacological inhibition or genetic deletion of FAAH tended to promote an obesogenic state in animal models, though the relationships between human $F A A H$ polymorphisms and obesity-related outcomes were heterogeneous, which could be due to FAAH having both pro-appetitive and anti-appetitive substrates. Genetic deletion of Mgll and Dagla as well as pharmacological inhibition of DAGL tended to reduce body weight and improve metabolic state in animal studies, though the effects of Mgll manipulation were tissue-dependent. Monitoring changes in body weight in ongoing clinical trials of FAAH inhibitors may clarify whether FAAH inhibition is a potential therapeutic strategy for treatment obesity. More preclinical work is needed to characterize the role of MAGL and DAGL modulation in obesity-related outcomes.

Keywords: obesity; endocannabinoid system; FAAH; MAGL; DAGL

\section{Introduction}

Obesity is a significant and ever-growing public health concern defined by a body mass index (BMI) of greater than $30 \mathrm{~kg} / \mathrm{m}^{2}$. Global data indicate that age-standardized obesity rates rose from $3.2 \%$ in 1975 to $10.8 \%$ in 2014 for men and from $6.4 \%$ in 1975 to $14.9 \%$ in 2014 for women [1]. The latest data from the NCD Risk Factor Collaboration showed that in 2016, almost 2 billion adults (39\% of the global adult population) were estimated to be overweight (BMI $\geq 25 \mathrm{~kg} / \mathrm{m}^{2}$ ) and 671 million (12\% of the global adult population) 
had obesity [2]. Obesity has been associated with numerous adverse health outcomes, including increased incidence of type II diabetes, cancers, and cardiovascular disease [3], and has both direct (medical) and indirect (nonmedical) costs that pose a significant global economic burden [4]. Developing effective therapeutic strategies to treat obesity is thus a global health priority.

The endocannabinoid system (ECS) was recognized as a potential target for obesity treatment in the early 2000's [5]. The ECS is an evolutionarily conserved lipid signalling system that has widespread involvement in nearly all physiological processes, including energy homeostasis, synaptic plasticity, and feeding behaviours [6]. The major components of the ECS include: two canonical G-protein coupled receptors, the cannabinoid type-1 (CB1) and type-2 (CB2) receptors; the endogenous ligands (endocannabinoids), which are phospholipid derivatives containing a poly-unsaturated fatty acid moiety and a polar head group, either ethanolamine in the case of arachidonoylethanolamide (anandamide; AEA) or glycerol in the case of 2-arachidonoylglycerol (2-AG); and the enzymes responsible for the synthesis and degradation of the endocannabinoids [7]. One major synthetic pathway for 2-AG involves the enzyme diacylglycerol lipase (DAGL), while AEA synthesis is more varied [6]. DAGL has two isoforms, DAGL $\alpha$ and DAGL $\beta$, which are encoded by two different human genes, DAGLA and DAGLB [8]. In terms of degradation, fatty acid amide hydrolase (FAAH), encoded by the human FAAH gene, is one of the most studied ECS enzymes, as it is responsible for the majority of AEA metabolism and is involved to a lesser extent in 2-AG metabolism [7]. Similarly, monoacylglycerol lipase (MAGL), encoded by the human MGLL gene, is responsible for the majority of 2-AG metabolism [7]. See Figure 1 for an overview of the ECS.

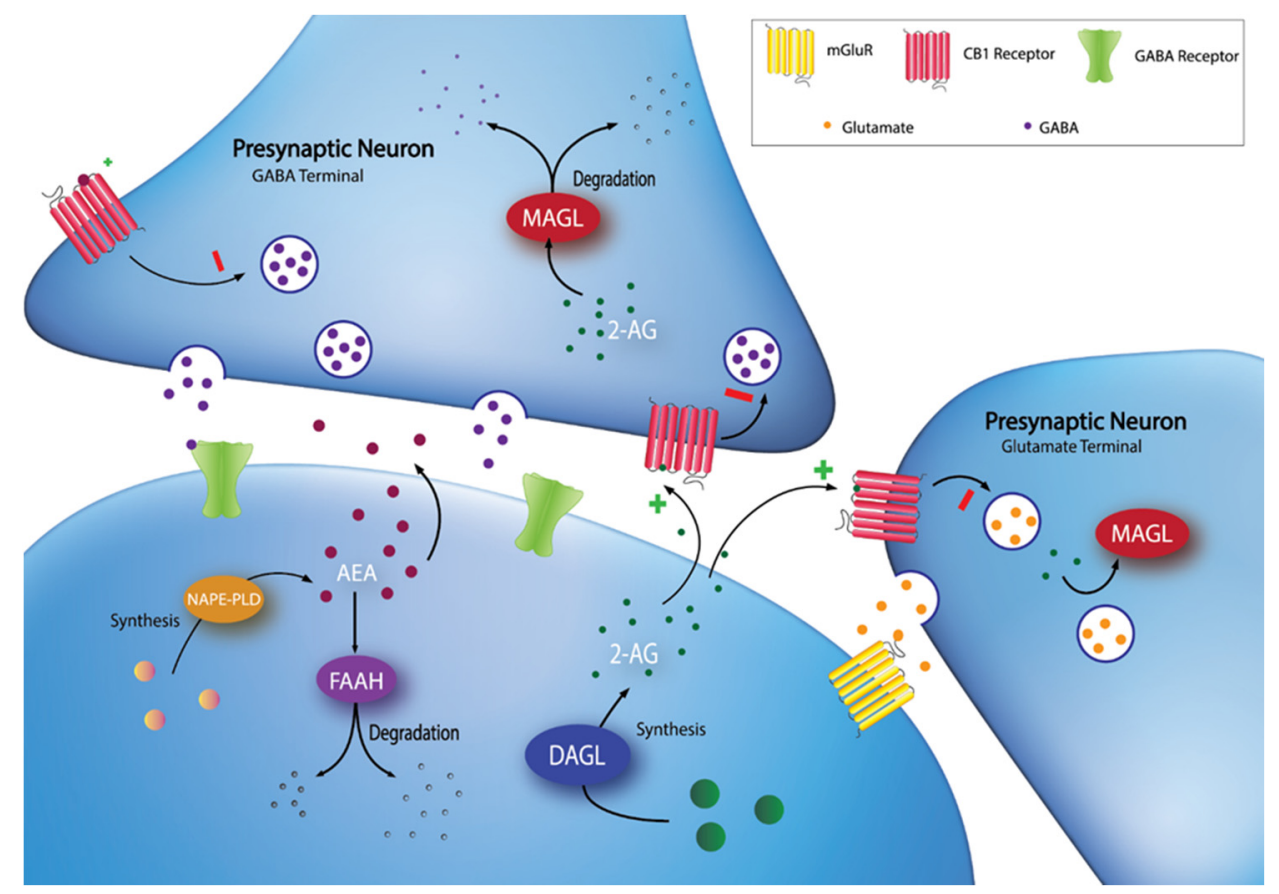

Figure 1. Synaptic localization of endocannabinoid synthesis and degradation. 2-AG is synthesized on-demand in the postsynaptic neuron by DAGL. Following synthesis, 2-AG diffuses into the synaptic cleft and activates $\mathrm{CB} 1$ receptors at GABA and glutamate terminals. 2-AG signaling can be terminated by MAGL degradation in the presynaptic terminal. AEA can be synthesized through multiple pathways (e.g., through a pathway involving NAPE-PLD), then diffuses into the synapse to activate $\mathrm{CB} 1$ receptors. Extracellular AEA undergoes reuptake into the postsynaptic cell and is hydrolyzed by FAAH.

The ECS has a multi-faceted role in the control of food intake and body weight, and it acts through both peripheral and central mechanisms. In the periphery, activation of 
CB1 receptors (e.g., by binding of AEA or 2-AG) promotes fat storage in adipocytes and increases lipogenesis, increases glucose uptake, and reduces satiety signals [9]. Centrally, activation of the ECS interferes with the control of hunger and satiety in multiple brain regions, including the hypothalamus and brain stem [9]. This likely involves a complex interplay between endocannabinoids and other neurotransmitters or hormones involved in hunger and satiety such as cholecystokinin (CCK), glucagon-like peptide 1 (GLP-1), and neuropeptide Y (NPY) [9]. Since the primary physiological function of the ECS is thought to shift energy balance towards energy storage, overactivation of the ECS likely contributes to obesity [5]. Numerous studies have found a positive association between circulating levels of endocannabinoids (AEA and/or 2-AG) and obesity in humans [10-12]. The elevated levels of endocannabinoids in human obesity are related to diet [13] and have been found to decrease after bariatric surgery [14].

Given that activation of the ECS increases food intake and energy storage, and that excessive activation of the ECS contributes to the pathogenesis of obesity, antagonism of the ECS has been explored as a potential therapeutic strategy $[5,15]$. In the early to mid-2000's, the multi-center Rimonabant in Obesity (RIO) trials found significant evidence that rimonabant, a CB1 receptor antagonist/inverse agonist, reduced body weight in adults with obesity, and improved other secondary measures such as dyslipidemia and cardiometabolic risk factors $[16,17]$. Unfortunately, the promise of rimonabant as an obesity treatment was short-lived, as it was withdrawn from the market due to mounting evidence of serious psychiatric adverse effects, including increased risk of suicidal ideation and depression [18-20]. The promise of rimonabant to treat obesity led to efforts to develop and test numerous other CB1 receptor ligands that might have potential to modulate body weight and treat obesity. Interested readers are directed to our previous review of CB1 receptor ligands and their potential to treat obesity [15]. In brief, some potential strategies to target the $\mathrm{CB} 1$ receptor without producing serious psychiatric adverse effects include peripherally-restricted CB1 inverse agonists, CB1 receptor partial agonists, and CB1 receptor neutral antagonists.

Rather than directly targeting the CB1 receptor, another potential strategy to modulate ECS activity is to target the enzymes responsible for synthesis and/or degradation of the endocannabinoids. Two approaches can be undertaken: (1) targeting endocannabinoid degradation, i.e., by inhibiting FAAH or MAGL, and (2) targeting endocannabinoid biosynthesis, i.e., by inhibiting DAGL or another synthetic enzyme [8]. Given that obesity is associated with enhanced endocannabinoid tone, inhibiting endocannabinoid biosynthesis (e.g., with a DAGL inhibitor) is the most biologically plausible approach. However, the activity of ECS enzymes is complex, so it is hard to predict the effect of inhibiting ECS enzymes. For example, in some tissues FAAH inhibition may target 2-AG in addition to $\mathrm{AEA}$, and it can both increase and decrease 2-AG concentrations [21]. There are also other substrates of FAAH that have a role in metabolism and satiety such as oleoylethanolamine (OEA) and palmitoylethanoamine (PEA). OEA is notable in particular as it has been shown to reduce food intake and suppress appetite, which is opposite to the effects of the endocannabinoids [22]. As FAAH metabolizes both pro-appetitive and anti-appetitive lipids, inhibition of FAAH would be expected to have mixed effects on appetite and body weight. It should be also noted that AEA and 2-AG have complex regulations; for example, AEA has been shown to inhibit metabolism and actions of 2-AG in the striatum [23].

To date, previous reviews have highlighted the genetic association between variation in the $F A A H$ gene and obesity-related outcomes in humans $[9,24]$. However, no previous reviews have focused specifically on evidence for a potential role of ECS enzymes in obesity treatment. Thus, the goal of the present review was to systematically review the published empirical literature and qualitatively synthesize existing evidence that either pharmacological or genetic manipulation/variation of FAAH, MAGL, and DAGL might impact obesity-related outcomes. Since the published literature we identified for the present review was so heterogeneous in study design and outcomes, we decided to present this as a narrative review. 


\section{Search Strategy}

A search was conducted on 13 July 2021 in the PubMed database. The following terms were used in a Boolean search format: (FAAH OR "Fatty acid amide hydrolase" OR MAGL OR MGL OR “Monoacylglycerol lipase" OR DAGL OR DGL OR “Diacylglycerol lipase") AND (obesity). A single search was conducted that included both preclinical and clinical studies.

Inclusion of an article was determined on the basis of its design, intervention(s), and endpoint(s). In terms of design, only studies involving humans or animal models were included. With regards to intervention, the study needed to feature (1) administration of a FAAH, MAGL, or DAGL inhibitor AND/OR (2) investigation of genetic variation in FAAH, MGLL, or DAGLA genes. With either of these interventions, a connection to obesity-related endpoints was also necessary. Specifically, relevant endpoints included measures of (1) body weight or body mass index (BMI), (2) body fat composition or distribution, (3) food intake or feeding behaviour, (4) glycemic markers, and/or (5) lipid profiles. These endpoints were selected from a review on metabolic endpoints in animal models of obesity [25]. Studies were included only when the title and/or abstract made an explicit mention of obesity, body weight, or related endpoints.

A hierarchy of exclusion criteria was also established. Studies were first excluded if they were written in the wrong language (i.e., not English). Next, studies were excluded on the basis of wrong study design. Common studies excluded under this criterion were review / non-empirical articles, in vitro studies, and genetic studies that did not consider variants or polymorphisms in the relevant genes. Studies were then excluded if they used the wrong intervention. Namely, this applied to pharmacological studies that did not administer a FAAH, MAGL, or DAGL inhibitor. Finally, studies were excluded if they did not measure an obesity-related outcome.

Figure 2 provides a Preferred Reporting Items for Systematic Reviews and MetaAnalyses (PRISMA) flowchart of the screening process for this review, conducted through Covidence. The initial search on July 13 produced 1235 studies from the PubMed database. During title and abstract screening, two reviewers were assigned to each article, and 1160 studies were removed. Seventy-five studies were left for full-text eligibility screening, and in this phase, 30 studies were excluded: 1 for wrong language, 18 for wrong study design, 7 for wrong intervention, and 4 for wrong outcomes. Ultimately, 45 studies were included for data extraction. During full-text eligibility screening, each article was also reviewed by two reviewers. 


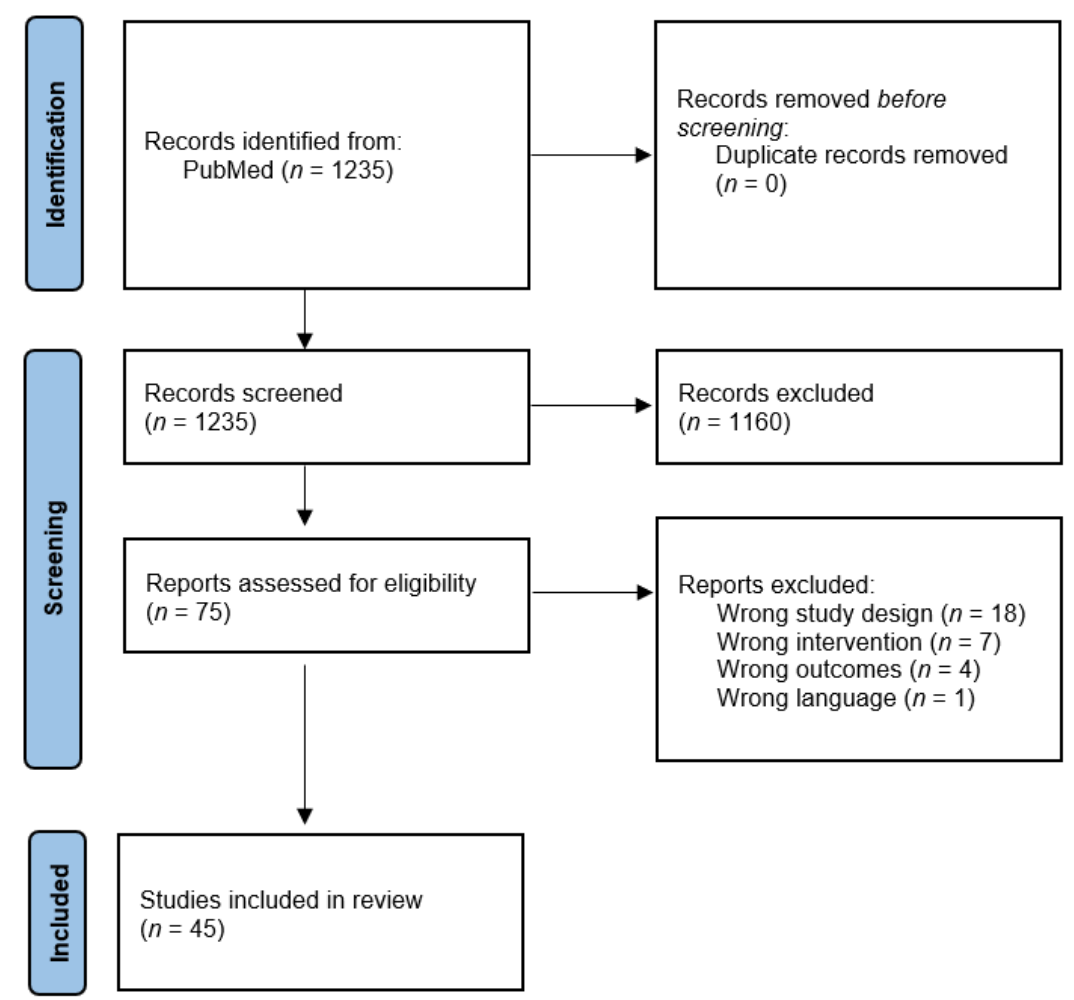

Figure 2. Flow diagram depicting the process of article identification, screening, and inclusion according to Preferred Reporting Items for Systematic Reviews and Meta-Analyses (PRISMA) guidelines. Both preclinical and clinical studies were included in the same article screening process.

\section{Current Evidence for a Role of Modulating FAAH, MAGL, and DAGL Activity in Obesity-Related Outcomes}

\subsection{Animal Studies Involving Pharmacological Manipulation}

We identified 5 animal studies that administered a pharmacological inhibitor of FAAH or DAGL and measured an obesity-related outcome (see Table 1).

Balsevich et al. (2018) investigated the role of FAAH in hypophagic responses to leptin [26]. Following a period of food deprivation, leptin administration induced expected reductions in body weight gain and food intake in saline-treated mice. Animals pre-treated with the FAAH inhibitor URB597 did not show these satiety responses following leptin treatment, suggesting that FAAH inhibition suppresses the effects of leptin on body weight and food intake. In another study, pharmacological inhibition of FAAH with PF-3845 had no effect on energy storage in rats [27]. Following exposure to a high-fat diet, PF-3845 and saline-treated animals showed similar decreases in body weight and food intake.

Stearoyl-CoA desaturase-1 (SCD1) is an enzyme involved in the synthesis of endogenous monounsaturated fatty acids (MUFAs). Due to its role in obesity, Liu et al. (2013) investigated functional interactions between SCD1 and ECS activity and found that MUFAs act as endogenous inhibitors of FAAH [28]. Under a high-fat diet, SCD1 knockout mice remained insulin-sensitive and glucose-tolerant compared to wildtype mice. When SCD1deficient mice were treated with the FAAH inhibitor URB597, they became insulin resistant and showed increased sensitivity to glucose. Endogenous FAAH inhibition resulting from the SCD1-mediated production of MUFAs may thus contribute to the hyperinsulinemic phenotype in response to high-fat diets.

Two studies also investigated the use of DAGL inhibitors with obesity-related outcomes. Bisogno et al. (2013) found that the DAGL $\alpha$ inhibitor O-7460 significantly and dose-dependently reduced food intake in male mice under a high-fat diet [29]. The highest dose of O-7460 $(12 \mathrm{mg} / \mathrm{kg})$ was also associated with a small yet significant decrease in body weight. Palma-Chavez et al. (2019) used a shRNA DAGL $\alpha$-inhibiting adenovirus to target 
tancytes of the hypothalamus and observed expression patterns of orexigenic (NPY) and anorexigenic (POMC) neuropeptides [30]. In fasting conditions, DAGL $\alpha$ inhibition was associated with reduced orexigenic and increased anorexigenic neuropeptides. Following glucose administration, DAGL $\alpha$ inhibition increased orexigenic and decreased anorexigenic neuropeptide expression. Control rats showed opposite responses in both conditions. Taken together, these findings indicate that DAGL $\alpha$ may regulate feeding behavior through the modulation of tancytic neuropeptides. DAGL $\alpha$ inhibition may reduce feeding through resulting decreases in $2-\mathrm{AG}$.

Table 1. Studies in animal models evaluating the impact of pharmacological manipulation of FAAH or DAGL enzymes on obesity-related outcomes.

\begin{tabular}{|c|c|c|c|}
\hline Reference & Species/Strain and Sex & $\begin{array}{l}\text { Drug, Dose, and Route } \\
\text { of Administration }\end{array}$ & Key Findings \\
\hline \multicolumn{4}{|c|}{ FAAH Inhibitors } \\
\hline $\begin{array}{l}\text { Balsevich et al. } \\
\quad \text { (2018) [26] }\end{array}$ & C57BL/ 6 mice, male & $0.3 \mathrm{mg} / \mathrm{kg}$ of URB597 i.p. & $\begin{array}{l}\text { After a 12-h overnight fast followed by } \\
\text { treatment with URB597, leptin } \\
\text { administration was unable to significantly } \\
\text { reduce body weight gain or food intake }\end{array}$ \\
\hline $\begin{array}{l}\text { Cifani et al. } \\
(2020)[27]\end{array}$ & Sprague-Dawley rats, male & $10 \mathrm{mg} / \mathrm{kg}$ of PF-3845 i.p. & No significant impact on body weight \\
\hline $\begin{array}{l}\text { Liu et al. } \\
\text { (2013) [28] }\end{array}$ & $\begin{array}{l}\text { C57BL/6 and SV/129 mice, } \\
\text { male }\end{array}$ & $5 \mathrm{mg} / \mathrm{kg}$ of URB597 i.p & $\begin{array}{l}S C D 1^{-/-} \text {mice fed a HFD demonstrated } \\
\text { glucose intolerance and insulin resistance } \\
\text { after treatment with URB597 } \\
S C D 1^{-/-} \text {mice fed a HFD had significantly } \\
\text { higher levels of plasma insulin after } \\
\text { URB597 administration }\end{array}$ \\
\hline \multicolumn{4}{|c|}{ DAGL Inhibitors } \\
\hline $\begin{array}{l}\text { Bisogno et al. } \\
\text { (2013) [29] }\end{array}$ & C57BL/ 6 mice, male & $\begin{array}{c}\text { O-7460 i.p.; } 0 \mathrm{mg} / \mathrm{kg}, \\
6 \mathrm{mg} / \mathrm{kg} \text {, and } 12 \mathrm{mg} / \mathrm{kg}\end{array}$ & $\begin{array}{c}\text { O-7460 dose-dependently decreased intake } \\
\text { of a HFD over } 14 \mathrm{~h} \\
\text { O-7460 (12 mg/kg) significantly decreased } \\
\text { body weight at } 14 \mathrm{~h}\end{array}$ \\
\hline $\begin{array}{l}\text { Palma-Chavez } \\
\text { et al. (2019) [30] }\end{array}$ & Sprague-Dawley rats, female & $\begin{array}{l}30 \mu \mathrm{L} \text { (at } 5 \times 10^{7} \mathrm{IFU} / \mathrm{mL} \text { ) of } \\
\text { shRNA DAGL } \alpha \text {-inhibiting } \\
\text { adenovirus; administered into } \\
\text { third ventricle }\end{array}$ & $\begin{array}{l}\text { In fasting conditions, inhibition of DAGL } \alpha \\
\text { reduced NPY and increased POMC } \\
\text { expression; in response to glucose, DAGL } \alpha \\
\text { inhibition increased NPY expression but } \\
\text { decreased POMC (opposite in control rats) }\end{array}$ \\
\hline
\end{tabular}

DAGL, diacylglycerol lipase; FAAH, fatty acid amide hydrolase; HLD, high-fat diet; i.p., intraperitoneal; NPY, neuropeptide Y; POMC, proopiomelanocortin.

\subsection{Animal Studies Involving Genetic Manipulation}

We identified 11 preclinical studies involving the genetic manipulation of Faah, Mgll, or Dagla that reported obesity-related outcomes (see Table 2). All studies used C57BL/6 mouse models.

The genetic deletion of Faah consistently produced obesity-related phenotypes across studies, as expected from resulting increases in AEA signaling. Greater body weight, fat mass, and triglyceride levels were observed in Faah knockout mice compared to wildtype under both standard and high-fat diets [31,32]. Faah-deficient mice also showed hepatic insulin resistance, which was associated with elevated liver triglyceride and diacylglycerol content [33]. The obesity phenotype found by Vaitheesvaran et al. (2012) in Faah-deficient mice was accompanied with greater total food intake under a regular diet [32]. In contrast, Touriño et al. (2010) found no effect of Faah deletion on food intake under either a standard or a high-fat diet [31]. However, Faah knockout mice showed greater reinforcement and motivational responses to food. 
The FAAH C385A polymorphism is a common loss-of-function mutation in humans. The A-allele results in lower FAAH expression and has been associated with heightened obesity risk. Balsevich et al. (2018) generated a knock-in model of this variant and found impaired leptin sensitivity in A385A mice [26]. The expected reductions in food intake and body weight following leptin treatment seen in wildtype were absent in transgenic mice, suggesting a role of FAAH in leptin satiety responses.

In addition to hydrolyzing N-acylethanolamines (NAEs) such as AEA, FAAH terminates the signaling activity of N-acyl taurines (NATs). Grevengoed et al. (2019) engineered a Faah knock-in model that selectively impaired NAT catabolism without affecting NAE degradation [34]. The S268D substitution did not replicate the obesity phenotypes found in the other studies. Instead, transgenic mice showed an improved metabolic profile compared to wildtypes. These findings confirm that obesity phenotypes found in Faah-deficient models are the result of endocannabinoid accumulation rather than increased NATs. Elevated NAT levels may instead have beneficial effects on energy storage and metabolism, which remain to be investigated.

Five studies investigated the role of $\mathrm{Mgll}$ in energy storage and obesity-related measures. Overexpression of $\mathrm{Mgll}$ in forebrain neurons lowered endocannabinoid levels, causing expected reductions in weight gain and adiposity [35]. Interestingly, intestinal overexpression of $\mathrm{Mgll}$ produced the opposite phenotype, characterized by increased body fat mass and weight gain [36]. These contradicting findings may reflect tissue-specific functions of MAGL. Similarly, under an obesogenic diet, the genetic deletion of $\mathrm{Mgll}$ was associated with paradoxical improvements in metabolic function. Compared to wildtypes, Mgll-deficient mice experienced less weight gain, had lower plasma triglyceride levels, and lower hepatic triglyceride content $[37,38]$. Insulin sensitivity and glucose tolerance were also improved [38]. Under a low-fat diet, knockout mice had lower fat mass and body weight despite showing no significant differences in food intake [39]. Reduced triglyceride and cholesterol levels were also found in male $M g l l$ knockout mice, under both low and high-fat diets. When males and females were considered together, this effect was only found in response to a high-fat diet. The potential sex-specific effects of $M g l l$ function on energy storage were not investigated by the other studies, as they included only male mice.

Our search identified only one genetic manipulation study on Dagla and obesityrelated measures. Powell et al. (2015) found that Dagla deletion improved metabolic function [40]. Compared to wildtype, knockout mice had reduced body weight, fat mass, total triglycerides and cholesterol. Food intake and fasting insulin levels were also reduced in Dagla-deficient mice.

Table 2. Studies in animal models evaluating the impact of genetic manipulation of Faah or Mgll on obesity-related outcomes.

\begin{tabular}{|c|c|c|c|}
\hline Reference & Species/Strain and Sex & $\begin{array}{l}\text { Gene(s) of Interest and } \\
\text { Genetic Manipulation * }\end{array}$ & Key Findings \\
\hline $\begin{array}{l}\text { Balsevich et al. } \\
\quad \text { (2018) [26] }\end{array}$ & C57BL/ 6 mice, male & $\begin{array}{l}\text { Mouse line with Faah C385A } \\
\text { knock-in }\end{array}$ & $\begin{array}{l}\text { After a 16-h overnight fast, C385A knock-in } \\
\text { mice did not demonstrate an expected } \\
\text { decrease in cumulative food intake or body } \\
\text { weight after leptin administration }\end{array}$ \\
\hline $\begin{array}{l}\text { Brown et al. } \\
(2012)[33]\end{array}$ & $\begin{array}{l}\text { 129SvJ-C57BL/ } 6 \text { mice, both } \\
\text { male and female }\end{array}$ & Faah $^{-/-}$mice & $\begin{array}{c}\text { Faah }^{-/} \text {mice had significantly high levels } \\
\text { of liver triglycerides and liver } \\
\text { diacylglycerols compared to WT mice } \\
\text { Deletion of Faah resulted in ectopic lipid } \\
\text { accumulation at the liver }\end{array}$ \\
\hline $\begin{array}{l}\text { Chon et al. } \\
\text { (2012) [36] }\end{array}$ & C57/BL6J-SJL mice, male & $\begin{array}{l}\text { Small intestine } M g l l \text { was } \\
\text { overexpressed in mice (iMGL } \\
\text { mice) }\end{array}$ & $\begin{array}{l}\text { After three weeks of a HFD, iMGL mice (vs. } \\
\text { WT) had significantly greater weight gain, } \\
\text { increased percent body fat, increased } \\
\text { adipose tissue mass, greater ectopic fat } \\
\text { depositions in the liver and small intestine, } \\
\text { and increased foot intake with reduced } \\
\text { energy expenditure }\end{array}$ \\
\hline
\end{tabular}


Table 2. Cont.

\begin{tabular}{|c|c|c|c|}
\hline Reference & Species/Strain and Sex & $\begin{array}{l}\text { Gene(s) of Interest and } \\
\text { Genetic Manipulation * }\end{array}$ & Key Findings \\
\hline $\begin{array}{l}\text { Douglass et al. } \\
\quad(2015)[39]\end{array}$ & $\begin{array}{l}\text { 129/SvEv-C57BL/6 mice, } \\
\text { both male and female }\end{array}$ & $M_{g} l^{-/-}$mice & $\begin{array}{l}\text { At baseline, } M g l l-/- \text { and WT mice did not } \\
\text { differ in body weight } \\
\text { Throughout } 12 \text { weeks of feeding, } M g l l-/- \\
\text { mice had lower body weight compared to } \\
\text { WT mice, in both males and females, and } \\
\text { under both HFD and low-fat diets LFD } \\
\text { At baseline and after } 12 \text { weeks of low-fat } \\
\text { dieting, Mgll - - mice had a significantly } \\
\text { lower fat mass than WT mice } \\
\text { Throughout the } 12 \text {-week feeding period, } \\
\text { there were no significant differences in } \\
\text { cumulative or average daily food intake; } \\
\text { after the feeding period, LFD-fed male } M g l l \\
\text { - /- mice had a significantly higher } \\
\text { cumulative food intake } \\
\text { Male } M g l l-/- \text { mice had significantly } \\
\text { lower triglyceride and cholesterol levels } \\
\text { under both diets; when considering both } \\
\text { sexes, only } M g l l-/- \text { fed a HFD } \\
\text { demonstrated significantly lower } \\
\text { triglyceride and cholesterol levels }\end{array}$ \\
\hline
\end{tabular}

Single amino-acid substitution in Faah (S268D) that

Grevengoed et al. (2019) [34]

C57BL/6N mice, male selectively disrupts $N$-acyl taurine (NAT) but not $\mathrm{N}$-acylethanolamine (NAE) hydrolytic activity
Jung et al. (2012) [35]
Mgll gene; generation of mice with forebrain neurons overexpressing Mgll (using CaMKII $\alpha$ promoter)
Faah-S268D mice had improved insulin sensitivity, increased glucagon secretion after insulin, and lower food intake in response to leptin treatment compared to WT mice

Mgll-overexpressing mice showed reduced weight gain, decreased adiposity, and increased lean mass compared to WT mice; this was accompanied by lower plasma triglyceride levels, decreased serum glucose levels, and increased glucose uptake despite increased frequency of feeding and greater food intake

Mgll-overexpressing mice were resistant to diet-induced obesity compared to WT

Dagla KO mice had significantly lower body weight and body fat mass compared to WT mice (under both chow-fed and HFD)

129S5/SvEvBrd $x$
Powell et al. $\begin{gathered}\text { C57BL/6-Tyr }{ }^{\mathrm{c}-\text { Brd }} \text { mice, both } \\ \text { (2015) [40] }\end{gathered}$

Powell et al. (2015) [40]
Dagla and Daglb genes; generation of Dagla KO, Daglb $\mathrm{KO}$, and Dagla/Daglb double $\mathrm{KO}$ mice
Dagla KO mice had significantly lower total food intake compared to WT mice Dagla KO mice had significantly lower fasting insulin, total triglyceride, and total cholesterol compared to WT mice 
Table 2. Cont.

\begin{tabular}{|c|c|c|c|}
\hline Reference & Species/Strain and Sex & $\begin{array}{l}\text { Gene(s) of Interest and } \\
\text { Genetic Manipulation* }\end{array}$ & Key Findings \\
\hline $\begin{array}{c}\text { Tardelli et al. } \\
\text { (2019) [37] }\end{array}$ & C57BL/ 6 mice, male & $\mathrm{Mgll}^{-/-}$mice & $\begin{array}{l}\text { Under either chow or Western diet, } M g l l \\
\text {-/- mice experienced significantly less } \\
\text { weight gain compared to WT mice, but } \\
M g l l-/- \text { mice had a significantly greater } \\
\text { gonadal white adipose tissue to body } \\
\text { weight ratio; no significant differences in } \\
\text { food intake } \\
M g l l-/- \text { fed under a Western diet had } \\
\text { significantly lower levels of plasma and } \\
\text { hepatic triglycerides and plasma insulin } \\
\text { compared to WT mice; no significant } \\
\text { differences in plasma cholesterol }\end{array}$ \\
\hline
\end{tabular}

$\mathrm{Faah}^{-/-}$mice had significantly greater body weight (standard diet and high-fat diet) compared to WT mice; this difference increased over time in $\mathrm{Faah}^{-1}$ mice fed with the HFD

Touriño et al. (2010) [31]
129SvJ-C57BL/ 6 mice, male

Faah $^{-/-}$mice
No significant effect on total food intake; however, $\mathrm{Fahh}^{-/-}$mice demonstrated greater reinforcement and motivation effects from food

When fed a HFD, Faah ${ }^{-1-}$ mice had significantly higher fat mass, triglyceride levels, glucose, and insulin levels compared to WT mice

Faah ${ }^{-/-}$mice had significantly higher body weight, food intake (regular chow diet), and fat mass compared to WT mice Faah $^{-/-}$mice had significantly higher levels of plasma insulin and plasma triglycerides compared to WT mice

Vaitheesvaran
et al. (2012) [32] C57BL $/ 6$ mice, male

$\mathrm{Mgll}^{-/-}$and WT mice had similar body weight gain and food intake when fed a normal chow diet; however, when fed a HFD, $\mathrm{Mgll}^{-/-}$mice gained less weight compared to WT mice $\mathrm{Mgll}{ }^{-/-}$mice had significantly better Yoshida et al. (2019) [38]
$\mathrm{Mgll}^{-/-}$mice glucose tolerance and insulin sensitivity compared to WT mice

$\mathrm{Mgll}^{-/-}$mice had significantly lighter

liver weights compared to WT mice, indicative of less ectopic fat accumulation in the liver

Following oral gavage with olive oil, $\mathrm{Mgll}$ -/ - mice had significantly lower plasma triglyceride levels compared to WT mice

* All gene knock-outs are global knock-outs unless otherwise indicated. Dagla, diacylglycerol lipase $\alpha$; Daglb, diacylglycerol lipase $\beta$; Faah, fatty acid amide hydrolase; HLD, high-fat diet; KO, knock-out; LFD, low-fat diet; Mgll, monoacylglycerol lipase; WT, wildtype.

\subsection{Human Studies Involving Genetic Association}

We identified 30 studies that included association between a FAAH or MGLL gene variant and any obesity-related outcome in a human sample (see Table 3). No studies were identified involving DAGLA or DAGLB gene variants. All 30 studies included at least one $F A A H$ variant, with only 3 studies additionally examining variation in $M G L L$. 
The majority of studies (26 out of 30) included one specific FAAH SNP, a missense mutation (C385A) associated with a change in amino acid sequence at position 129 from proline to threonine (Pro129Thr). This SNP was originally identified in 2002 and was found to be strongly associated with problematic substance use [41]. The Pro129Thr variant was found to have normal catalytic activity but an enhanced sensitivity to proteolytic degradation [41]. Subsequent functional characterization of the variant found that the mutant $F A A H$ enzyme had less than half of the expression and activity of the wildtype enzyme [42].

Of the 26 studies included in the present review, 19 found a significant association between the C385A SNP and at least one obesity-related outcome [43-61]. Following up on their initial discovery of the C385A SNP, Sipe and colleagues were the first to identify a significant association between the A allele and increased likelihood of being overweight or obese in a sample of 1688 White adults and 614 Black adults (but not in 365 Asian adults) [57]. In support of these findings, Monteleone et al. (2008) found that the A allele was significantly more common in women who were overweight or obese compared to healthy weight controls $(n=299)$ [55]. Yagin et al. (2019) similarly found the A allele to be more common in women who were overweight or obese $(n=180)$ compared to health weight controls $(n=86)$ [60]. Thethi et al. (2020) recently reported another significant association between the A allele and obesity, though the association was no longer significant when controlling for age, race, sex, waist-to-hip ratio, and cholesterol [58]. Further support for an association between the C385A variant and increased risk of obesity comes from studies including continuous outcomes. For example, the A allele was associated with higher BMI, fat mass, and waist circumference in a sample of 70 participants with Type-II diabetes mellitus who were obese [50]. Yagin et al. (2019) also found a significant association between the A allele and higher BMI, waist circumference, neck circumference, waist-to-height ratio, and body fat mass [60], while Zhang et al. (2009) found an association between the A allele and higher BMI and triglyceride levels in a sample of 1644 participants from 261 pedigrees [61]. Further, Vazquez-Roque et al. (2011) found that A-allele carriers had a significantly greater maximum tolerated volume after a nutrient drink test, indicating lower satiety [59].

In contrast, multiple studies have failed to replicate the association between the A allele and obesity. Seven studies found no significant association between the SNP and any obesity-related outcomes [62-68]. A few studies actually found the reverse associationeither a significant association between the wildtype (C/C) genotype and obesity $[53,56]$ or an association of the wildtype $(\mathrm{C} / \mathrm{C})$ genotype with worse cardiometabolic outcomes, e.g., higher triglycerides and metabolic biomarkers [46]. Studies conducted by De Luis and colleagues failed to find any significant association between the C385A SNP and a wide range of obesity-related outcomes including anthropometric outcomes (BMI, body weight, waist circumference, etc.) and circulating lipids [44-49,51,52].

Interestingly, a number of studies have suggested that while the C385A SNP may not directly impact obesity-related outcomes at baseline, there may be an impact of the variant on changes in outcomes following either surgical or lifestyle interventions for obesity. Aberle et al. (2007) found that A-allele carriers had greater decreases in triglyceride and cholesterol levels after a 6-week low-fat diet intervention $(n=451$ obese and dyslipidemic participants) [43]. Similarly, De Luis et al. (2011) found that A-allele carriers had greater improvement in a range of metabolic outcomes after 3 months of a hypocaloric dietary intervention ( $n=122)$ [47], while De Luis et al. (2010) found greater weight loss in A-allele carriers at 9 and 12 months after biliopancreatic diversion surgery $(n=67)$ [51]. In contrast, three other studies by De Luis and colleagues found that the A-allele was associated with worse outcomes following either a low-fat or low-carbohydrate diet intervention for 3 months $(n=248)$ [52], and also following a 3-month enriched monounsaturated fat hypocaloric diet $(n=95)$ [44] and a 3-month enriched polyunsaturated fat hypocaloric diet $(n=99)$ [49]. Finally, Knoll et al. (2012) failed to show any association of the C385A variant 
and obesity-related outcomes after a 1-year diet and exercise intervention in a group of 453 overweight and obese children and adolescents [63].

In addition to examining associations between the $F A A H C 385 \mathrm{~A}$ variant and obesityrelated outcomes, four studies examined associations with other FAAH SNPs $[53,56,61,64]$. In a large sample of 5109 French Caucasian participants, Durand et al. (2008) failed to find an association between 10 FAAH SNPs and childhood obesity or Type-II diabetes mellitus, but did find a nominal association between 5 FAAH SNPs (rs6429600, rs324419, rs324418, rs2295633, and rs7520850) and Class III adult obesity [53]. Lieb et al. (2009) failed to find an association between 9 FAAH SNPs and obesity-related outcomes in a sample of 2415 participants from a longitudinal cohort [64]. Muller et al. (2010) found some additional evidence of association between $F A A H$ gene variants and obesity-the $\mathrm{G}$ allele of rs2295632 was associated with early-onset obesity in 521 trios (children/adolescents and both biological parents), though this finding did not replicate in a second cohort of trios, and there was no association with obesity in adults $(n=8491$ participants from a populationbased study sample) [56]. Finally, Zhang et al. (2009) did not find an association between four FAAH SNPs (rs324418, rs1984490, rs2145408 and rs4141964) and any obesity-related traits [61].

Three studies used bioinformatic approaches to identify novel genetic variants in FAAH and MGLL genes associated with obesity or obesity-related traits [69-71]. Bhatia et al. (2010) used data from a large clinical trial cohort $(n=289)$ to identify rare variants in FAAH and MGLL associated with obesity, and found one significantly associated region of approximately $5 \mathrm{Kbp}$ in the upstream regulatory region of each gene [69]. Harismendy et al. (2010) similarly used data from the same clinical trial cohort to identify one interval in the FAAH promoter and three intervals in MGLL (in the promoter, intron 2, and intron 3) that were all significantly associated with obesity [70]. Kuk et al. (2013) identified three potentially causal rare variants in MGLL associated with obesity, while also finding an interaction between two rare variants in FAAH that may increase the risk of obesity [71].

Table 3. Human studies examining genetic association between FAAH and/or MGLL and obesity-related outcomes.

\begin{tabular}{|c|c|c|c|}
\hline Reference & Sample & $\begin{array}{l}\text { Gene(s) and Variant(s) and } \\
\text { Study Design }\end{array}$ & Key Findings \\
\hline $\begin{array}{l}\text { Aberle et al. } \\
\text { (2007) [43] }\end{array}$ & $\begin{array}{c}n=451 \text { obese } / \text { overweight } \\
\left(\text { BMI }>25 \mathrm{~kg} / \mathrm{m}^{2}\right) \text { and } \\
\text { dyslipidemic }\end{array}$ & $\begin{array}{c}\text { FAAH-Pro129Thr SNP } \\
\text { (rs324420) } \\
\text { Genetic association with } \\
\text { obesity-related traits at } \\
\text { baseline and after a 6-week } \\
\text { diet intervention }\end{array}$ & $\begin{array}{l}\text { No baseline association } \\
\text { After six weeks of low-fat diet, there were } \\
\text { significant decreases in triglyceride and } \\
\text { total cholesterol levels in CA/AA vs. CC }\end{array}$ \\
\hline $\begin{array}{l}\text { Bhatia et al. } \\
\text { (2010) [69] }\end{array}$ & $\begin{array}{l}n=147 \text { with BMI }<30 \mathrm{~kg} / \mathrm{m}^{2} \\
n=142 \text { with BMI }>40 \mathrm{~kg} / \mathrm{m}^{2}\end{array}$ & $\begin{array}{l}\text { A novel algorithm called } \\
\text { RareCover used to analyze the } \\
\text { contribution of rare genetic } \\
\text { variants in } F A A H \text { and } M G L L \\
\text { to the development of obesity } \\
\text { phenotypes (based on BMI) }\end{array}$ & $\begin{array}{l}\text { Two } 5 \mathrm{Kbp} \text { regions in the upstream } \\
\text { regulatory segments of } F A A H \text { and } M G L L \\
\text { genes identified, rare variants that could } \\
\text { hinder } F A A H \text { and } M G L L \text { gene expression }\end{array}$ \\
\hline $\begin{array}{l}\text { De Luis et al. } \\
\text { (2010) [46] }\end{array}$ & $n=279$ obese females & $\begin{array}{l}\text { FAAH-Pro129Thr SNP } \\
\text { (rs324420) } \\
\text { Genetic association with } \\
\text { obesity-related traits }\end{array}$ & $\begin{array}{c}\text { No significant association with } \\
\text { anthropometric parameters or dietary } \\
\text { intake } \\
\text { A-allele significantly associated with lower } \\
\text { triglycerides, glucose, and HOMA }\end{array}$ \\
\hline $\begin{array}{l}\text { De Luis et al. } \\
\text { (2010) [48] }\end{array}$ & $n=143$ obese females & $\begin{array}{l}\text { FAAH-Pro129Thr SNP } \\
\text { (rs324420) } \\
\text { Genetic association with } \\
\text { obesity-related traits }\end{array}$ & $\begin{array}{c}\text { No significant differences in } \\
\text { anthropometric parameters or food intake } \\
\text { Significantly higher levels of glucose, } \\
\text { insulin, and HOMA in C/C (wildtype) vs. } \\
\text { A-allele carriers }\end{array}$ \\
\hline
\end{tabular}


Table 3. Cont.

\begin{tabular}{|c|c|c|c|}
\hline Reference & Sample & $\begin{array}{l}\text { Gene(s) and Variant(s) and } \\
\text { Study Design }\end{array}$ & Key Findings \\
\hline $\begin{array}{l}\text { De Luis et al. } \\
\text { (2010) [50] }\end{array}$ & $\begin{array}{l}n=70 \text { with Type-II Diabetes } \\
\text { Mellitus and obesity (BMI > } \\
\left.\qquad 30 \mathrm{~kg} / \mathrm{m}^{2}\right)\end{array}$ & $\begin{array}{c}\text { FAAH_Pro129Thr SNP } \\
\text { (rs324420) } \\
\text { Genetic association with } \\
\text { obesity-related traits }\end{array}$ & $\begin{array}{l}\text { A-allele carriers had significantly higher } \\
\text { BMI, fat mass, waist circumference, insulin, } \\
\text { HOMA, and lower adiponectin vs. } \\
\text { wildtype }(\mathrm{C} / \mathrm{C}) \\
\text { No significant difference in dietary intake }\end{array}$ \\
\hline $\begin{array}{l}\text { De Luis et al. } \\
\text { (2010) [51] }\end{array}$ & $\begin{array}{c}n=67 \text { with } \mathrm{BMI}>40 \mathrm{~kg} / \mathrm{m}^{2} \\
\text { who had undergone } \\
\text { biliopancreatic diversion }\end{array}$ & $\begin{array}{c}\text { FAAH-Pro129Thr SNP } \\
\text { (rs324420) } \\
\text { Genetic association with } \\
\text { obesity-related traits at } \\
\text { baseline, and then } 3,9 \text {, and } \\
12 \text { months after surgery }\end{array}$ & $\begin{array}{l}\text { No significant baseline differences in } \\
\text { anthropometric or biochemical parameters } \\
\text { At } 9 \text { and } 12 \text { months, weight loss was } \\
\text { greater in A-allele carriers vs. wildtype } \\
\text { (C/C) }\end{array}$ \\
\hline $\begin{array}{l}\text { De Luis et al. } \\
\text { (2010) [52] }\end{array}$ & $n=248$ with BMI $>30 \mathrm{~kg} / \mathrm{m}^{2}$ & $\begin{array}{c}\text { FAAH-Pro129Thr SNP } \\
\text { (rs324420) } \\
\text { Genetic association with } \\
\text { obesity-related traits at } \\
\text { baseline and after a 3-month } \\
\text { diet intervention (low fat or } \\
\text { low carbohydrate) }\end{array}$ & $\begin{array}{c}\text { No significant difference between } \\
\text { genotypes at baseline or } 3 \text { months in } \\
\text { anthropometric outcomes, cardiovascular } \\
\text { risk factors, or circulating adipocytokines } \\
\text { In both diet intervention groups, A-allele } \\
\text { carriers failed to show improvement in } \\
\text { glucose, insulin, HOMA, and leptin, while } \\
\text { wildtype }(\mathrm{C} / \mathrm{C}) \text { did }\end{array}$ \\
\hline $\begin{array}{l}\text { De Luis et al. } \\
\text { (2011) [47] }\end{array}$ & $n=122$ with $\mathrm{BMI}>30 \mathrm{~kg} / \mathrm{m}^{2}$ & $\begin{array}{c}\text { FAAH-Pro129Thr SNP } \\
\text { (rs324420) } \\
\text { Genetic association with } \\
\text { obesity-related traits at } \\
\text { baseline and after a 3-month } \\
\text { diet intervention (hypocaloric) }\end{array}$ & $\begin{array}{l}\text { At baseline, there were no genotype } \\
\text { differences in anthropometric or dietary } \\
\text { intake measures, but A-allele carriers had } \\
\text { significantly lower insulin, HOMA, and } \\
\text { C-reactive protein vs. wildtype (C/C) } \\
\text { After } 3 \text { months, weight, waist } \\
\text { circumference, insulin, C-reactive protein, } \\
\text { and triglyceride levels were lower in } \\
\text { A-allele carriers vs. wildtype (C/C), with } \\
\text { no difference in dietary intake }\end{array}$ \\
\hline $\begin{array}{l}\text { De Luis et al. } \\
\text { (2012) [45] }\end{array}$ & $\begin{array}{c}n=799 \text { with mean BMI of } \\
36.7 \mathrm{~kg} / \mathrm{m}^{2}\end{array}$ & $\begin{array}{l}\text { FAAH-Pro129Thr SNP } \\
\text { (rs324420) } \\
\text { Genetic association with } \\
\text { obesity-related traits and } \\
\text { metabolic syndrome }\end{array}$ & $\begin{array}{l}\text { No significant association with metabolic } \\
\text { syndrome } \\
\text { No significant differences in } \\
\text { anthropometric measures or circulating } \\
\text { adipocytokines by genotype, but insulin } \\
\text { and HOMA were significantly higher in } \\
\text { A-allele carriers vs. wildtype }(\mathrm{C} / \mathrm{C})\end{array}$ \\
\hline $\begin{array}{l}\text { De Luis et al. } \\
\text { (2013) [44] }\end{array}$ & $n=95$ with BMI $>30 \mathrm{~kg} / \mathrm{m}^{2}$ & $\begin{array}{c}\text { FAAH-Pro129Thr SNP } \\
\text { (rs324420) } \\
\text { Genetic association with } \\
\text { obesity-related traits at } \\
\text { baseline and after a 3-month } \\
\text { diet intervention (enriched } \\
\text { monounsaturated fat } \\
\text { hypocaloric) }\end{array}$ & $\begin{array}{l}\text { No significant differences at baseline } \\
\text { between genotypes } \\
\text { After } 3 \text { months, the wildtype group }(\mathrm{C} / \mathrm{C}) \\
\text { showed greater improvements in insulin, } \\
\text { HOMA-R, weight, fat mass, and waist } \\
\text { circumference vs. A-allele carriers }\end{array}$ \\
\hline $\begin{array}{l}\text { De Luis et al. } \\
\text { (2013) [49] }\end{array}$ & $n=99$ with $\mathrm{BMI}>30 \mathrm{~kg} / \mathrm{m}^{2}$ & $\begin{array}{c}\text { FAAH-Pro129Thr SNP } \\
\text { (rs324420) } \\
\text { Genetic association with } \\
\text { obesity-related traits at } \\
\text { baseline and after a 3-month } \\
\text { diet intervention (enriched } \\
\text { polyunsaturated fat } \\
\text { hypocaloric) }\end{array}$ & $\begin{array}{c}\text { No significant differences at baseline } \\
\text { between genotypes } \\
\text { After } 3 \text { months, there were no significant } \\
\text { genotype differences in anthropometric } \\
\text { parameter or adipokine changes, while } \\
\text { there was improvement in insulin and } \\
\text { HOMA-R in wildtype (C/C) vs. A-allele } \\
\text { carriers }\end{array}$ \\
\hline
\end{tabular}


Table 3. Cont.

\begin{tabular}{|c|c|c|c|}
\hline Reference & Sample & $\begin{array}{l}\text { Gene(s) and Variant(s) and } \\
\text { Study Design }\end{array}$ & Key Findings \\
\hline $\begin{array}{l}\text { Durand et al. } \\
\text { (2008) [53] }\end{array}$ & $\begin{array}{c}n=1340 \text { healthy adult controls } \\
n=635 \text { obese children } \\
n=896 \text { adults with Class III } \\
\text { obesity, i.e., BMI } \geq 40 \mathrm{~kg} / \mathrm{m}^{2} \\
n=2238 \text { adults with Type-II } \\
\text { Diabetes Mellitus }\end{array}$ & $\begin{array}{l}\text { FAAH-10 SNPs across the } \\
\text { entire FAAH locus, including } \\
\text { Pro129Thr SNP (rs324420); } \\
\text { rs913168, rs17361950, } \\
\text { rs6429600, rs324419, rs324418, } \\
\text { rs2295633, rs11576941, } \\
\text { rs324425, rs7520850 } \\
\text { Case-control genetic } \\
\text { association }\end{array}$ & $\begin{array}{l}\text { No significant associations with childhood } \\
\text { obesity or Type-II Diabetes Mellitus } \\
\text { Nominally significant association between } \\
\text { rs324420 (C allele was risk allele) and } \\
5 \text { other FAAH SNPs (rs6429600, rs324419, } \\
\text { rs324418, rs2295633, and rs7520850) and } \\
\text { Class III (adult) obesity } \\
\text { No significant association between } \\
\text { rs324420 SNP and metabolic traits }\end{array}$ \\
\hline $\begin{array}{l}\text { Grolmusz et al. } \\
\text { (2013) [54] }\end{array}$ & $\begin{array}{c}n=63 \text { patients with polycystic } \\
\text { ovary syndrome (mean BMI } \\
\left.29.6 \mathrm{~kg} / \mathrm{m}^{2}\right) \\
n=67 \text { healthy controls (mean } \\
\text { BMI } 21.2 \mathrm{~kg} / \mathrm{m}^{2} \text { ) }\end{array}$ & $\begin{array}{c}\text { FAAH-Pro129Thr SNP } \\
\text { (rs324420) } \\
\text { Case-control genetic } \\
\text { association }\end{array}$ & $\begin{array}{c}\text { In cases, free thyroxine was higher in } \\
\text { A-allele carriers than wildtype }(\mathrm{C} / \mathrm{C}) \\
\text { In controls, insulin was significantly lower } \\
\text { in A-allele carriers than wildtype }(\mathrm{C} / \mathrm{C}) \\
\text { No other significant associations (including } \\
\text { BMI) }\end{array}$ \\
\hline $\begin{array}{l}\text { Harismendy } \\
\text { et al. (2010) [70] }\end{array}$ & $\begin{array}{l}n=147 \text { with BMI }<30 \mathrm{~kg} / \mathrm{m}^{2} \\
n=142 \text { with BMI }>40 \mathrm{~kg} / \mathrm{m}^{2}\end{array}$ & $\begin{array}{l}\text { Sequence-based case-control } \\
\text { genetic association (FAAH and } \\
M G L L)\end{array}$ & $\begin{array}{l}\text { One interval in FAAH promoter and } \\
3 \text { intervals in } M G L L \text { (promoter, intron 2, } \\
\text { intron 3) were associated with obesity }\end{array}$ \\
\hline $\begin{array}{l}\text { Jensen et al. } \\
(2007)[62]\end{array}$ & $\begin{array}{c}n=5801 \text { classified as normal } \\
\text { weight }=\text { BMI } 18.5-25 \mathrm{~kg} / \mathrm{m}^{2} \\
\text { overweight }=\text { BMI } \\
25-30 \mathrm{~kg} / \mathrm{m}^{2}, \text { and } \\
\text { obese }=\text { BMI } \geq 30 \mathrm{~kg} / \mathrm{m}^{2}\end{array}$ & $\begin{array}{c}\text { FAAH-Pro129Thr SNP } \\
\text { (rs324420) } \\
\text { Genetic association }\end{array}$ & $\begin{array}{c}\text { No significant association with BMI or } \\
\text { waist circumference groups or with any } \\
\text { quantitative trait }\end{array}$ \\
\hline $\begin{array}{l}\text { Knoll et al. } \\
(2012)[63]\end{array}$ & $\begin{array}{c}n=453 \text { overweight or obese } \\
\text { children and adolescents } \\
(\text { mean } 10.8 \text { years old) }\end{array}$ & $\begin{array}{c}\text { FAAH-Pro129Thr SNP } \\
\text { (rs324420) } \\
\text { Genetic association with } \\
\text { obesity-related traits at } \\
\text { baseline and after a 1-year } \\
\text { lifestyle intervention }\end{array}$ & $\begin{array}{l}\text { No significant association with change in } \\
\text { any outcome }\end{array}$ \\
\hline $\begin{array}{l}\text { Kuk et al. (2013) } \\
\text { [71] }\end{array}$ & $\begin{array}{l}n=148 \text { with } \mathrm{BMI}>40 \mathrm{~kg} / \mathrm{m}^{2} \\
n=150 \text { with } \mathrm{BMI}<30 \mathrm{~kg} / \mathrm{m}^{2}\end{array}$ & $\begin{array}{l}\text { Sequence-based case-control } \\
\text { genetic association (FAAH and } \\
\text { MGLL) }\end{array}$ & $\begin{array}{c}\text { Three potentially causal rare variants were } \\
\text { identified around } M G L L \\
\text { An interaction between two rare variants } \\
\text { around } F A A H \text { was identified that may } \\
\text { increase the risk of obesity }\end{array}$ \\
\hline $\begin{array}{l}\text { Lieb et al. (2009) } \\
\text { [64] }\end{array}$ & $\begin{aligned} n= & 2415 \text { participants from a } \\
& \text { longitudinal cohort }\end{aligned}$ & $\begin{array}{l}F A A H-9 \text { SNPs across the } \\
\text { entire } F A A H \text { locus, including } \\
\text { Pro129Thr SNP (rs324420); } \\
\text { rs12073998, rs6703669, } \\
\text { rs3766246, rs324419, } \\
\text { rs2295633, rs12029329, } \\
\text { rs324425, rs7520850 } \\
\text { Genetic association }\end{array}$ & No significant associations \\
\hline $\begin{array}{l}\text { Mansouri et al. } \\
\text { (2020) [65] }\end{array}$ & $n=79$ healthy participants & $\begin{array}{c}\text { FAAH-Pro129Thr SNP } \\
\text { (rs324420) }\end{array}$ & $\begin{array}{l}\text { No significant difference in mean BMI } \\
\text { between genotypes }\end{array}$ \\
\hline $\begin{array}{l}\text { Martins et al. } \\
\text { (2015) [66] }\end{array}$ & $\begin{array}{c}n=100 \text { with BMI } \geq \\
18.5 \mathrm{~kg} / \mathrm{m}^{2} \text { and }<25 \mathrm{~kg} / \mathrm{m}^{2} \\
n=100 \text { with BMI } \geq 30 \mathrm{~kg} / \mathrm{m}^{2}\end{array}$ & $\begin{array}{c}\text { FAAH-Pro129Thr SNP } \\
\text { (rs324420) } \\
\text { Genetic association with } \\
\text { obesity and insulin-resistant } \\
\text { phenotype }\end{array}$ & No significant associations \\
\hline
\end{tabular}


Table 3. Cont.

\begin{tabular}{|c|c|c|c|}
\hline Reference & Sample & $\begin{array}{l}\text { Gene(s) and Variant(s) and } \\
\text { Study Design }\end{array}$ & Key Findings \\
\hline $\begin{array}{l}\text { Monteleone } \\
\text { et al. (2008) [55] }\end{array}$ & $\begin{array}{c}n=115 \text { overweight/obese } \\
\text { females with binge-eating } \\
\text { disorder (BED) } \\
n=74 \text { obese females without } \\
\text { BED } \\
n=110 \text { healthy controls }\end{array}$ & $\begin{array}{l}\text { FAAH-Pro129Thr SNP } \\
\text { (rs324420) } \\
\text { Case-control genetic } \\
\text { association }\end{array}$ & $\begin{array}{l}\text { A allele was significantly more frequent in } \\
\text { overweight/obese females compared to } \\
\text { controls }\end{array}$ \\
\hline $\begin{array}{l}\text { Muller et al. } \\
\text { (2010) [56] }\end{array}$ & $\begin{array}{c}n=521 \text { children and } \\
\text { adolescents }(\text { mean BMI } \\
\left.31.86 \mathrm{~kg} / \mathrm{m}^{2}\right) \text { and both } \\
\text { biological parents } \\
n=501 \text { German children and } \\
\text { adolescents (including one } \\
\text { sibling) }(\text { mean BMI } \\
32.28 \mathrm{~kg} / \mathrm{m}^{2} \text { ) and both } \\
\text { biological parents } \\
n=8491 \text { adults (mean BMI } \\
\left.27.12 \mathrm{~kg} / \mathrm{m}^{2}\right) \text { from a } \\
\text { population-based study group } \\
n=985 \mathrm{cases}(\text { mean BMI } \\
\left.36.04 \mathrm{~kg} / \mathrm{m}^{2}\right) \text { and } \\
n=588 \mathrm{controls}(\text { mean BMI } \\
\left.19.34 \mathrm{~kg} / \mathrm{m}^{2}\right)\end{array}$ & $\begin{array}{l}\text { FAAH-five SNPs, including } \\
\text { Pro129Thr SNP (rs324420); } \\
\text { rs324419, rs873978, } \\
\text { rs2295632 and rs932816 } \\
\text { Genetic association first in a } \\
\text { sample of trios, then } \\
\text { replicated in a second cohort } \\
\text { of families, then in combined } \\
\text { sample } \\
\text { SNPs significantly associated } \\
\text { with childhood obesity were } \\
\text { then screened in a } \\
\text { population-based cohort of } \\
\text { adults, and then in a } \\
\text { case-control sample }\end{array}$ & $\begin{array}{l}\text { Association of } \mathrm{G} \text { allele of } F A A H \\
\text { rs2295632 with early onset obesity in the } \\
\text { initial sample of trios, but this did not } \\
\text { replicate in the subsequent sample } \\
\text { When the two samples were combined, } \\
\text { FAAH rs324420 (C allele) and } \\
\text { rs2295632 were significantly associated } \\
\text { with childhood obesity } \\
\text { No significant association between FAAH } \\
\text { rs324420 or rs2295632 and adult obesity or } \\
\text { BMI in the population-based sample; no } \\
\text { significant association with rs324420 in the } \\
\text { case-control analysis }\end{array}$ \\
\hline $\begin{array}{l}\text { Ning et al. (2017) } \\
\text { [72] }\end{array}$ & $\begin{array}{l}n=227 \text { with BMI } \\
35.1-61.7 \mathrm{~kg} / \mathrm{m}^{2} \\
n=219 \text { with BMI } \\
17.5-23.0 \mathrm{~kg} / \mathrm{m}^{2}\end{array}$ & $\begin{array}{l}\text { FAAH-whole-exome } \\
\text { sequencing }\end{array}$ & $\begin{array}{l}\text { The novel FAAH c.G944T (p.R315I) variant } \\
\text { co-segregated with obesity in the } \\
\text { proband's pedigree; in vitro } \\
\text { characterization of } F A A H \text {-R315I suggested } \\
\text { that it is a loss-of-function mutation }\end{array}$ \\
\hline $\begin{array}{l}\text { Papazoglou et al. } \\
\text { (2008) [67] }\end{array}$ & $\begin{array}{c}n=158 \text { with } \mathrm{BMI}>40 \mathrm{~kg} / \mathrm{m}^{2} \\
n=145 \text { with } \mathrm{BMI}>40 \mathrm{~kg} / \mathrm{m}^{2} \\
\text { and metabolic syndrome } \\
n=121 \text { with BMI } \\
18.5-25 \mathrm{~kg} / \mathrm{m}^{2}\end{array}$ & $\begin{array}{l}\text { FAAH-Pro129Thr SNP } \\
\text { (rs324420) } \\
\text { Case-control genetic } \\
\text { association }\end{array}$ & No significant associations \\
\hline $\begin{array}{l}\text { Sipe et al. (2005) } \\
{[57]}\end{array}$ & $\begin{array}{l}n=2667 \text { (1688 White, } \\
614 \text { Black, } 365 \text { Asian) }\end{array}$ & $\begin{array}{l}\text { FAAH-Pro129Thr SNP } \\
\text { (rs324420) } \\
\text { Case-control genetic } \\
\text { association }\end{array}$ & $\begin{array}{l}\text { Significant association of A/A genotype } \\
\text { with overweight/obese status in Black and } \\
\text { White, but not Asian, participants } \\
\text { Median BMI was higher in the A/A } \\
\text { genotype group compared to C/A + C/C } \\
\text { in the pooled sample }\end{array}$ \\
\hline $\begin{array}{l}\text { Thethi et al. } \\
\text { (2020) [58] }\end{array}$ & $\begin{array}{l}n=465 \text { with } \mathrm{BMI} \geq 30 \mathrm{~kg} / \mathrm{m}^{2} \\
n=202 \text { with } \mathrm{BMI} \leq 27 \mathrm{~kg} / \mathrm{m}^{2}\end{array}$ & $\begin{array}{l}\text { FAAH-Pro129Thr SNP } \\
\text { (rs324420) } \\
\text { Case-control genetic } \\
\text { association }\end{array}$ & $\begin{array}{l}\text { Significant association of the A allele with } \\
\text { obesity, but not when adjusting for age, } \\
\text { race, sex, waist-hip ratio, and LDL } \\
\text { No association with any other outcome } \\
\text { measure }\end{array}$ \\
\hline $\begin{array}{l}\text { Vazquez-Roque } \\
\text { et al. (2011) [59] }\end{array}$ & $\begin{array}{c}n=62 \text { adults overweight or } \\
\text { obese }(n=5 \text {, mean BMI } \\
24.0 \mathrm{~kg} / \mathrm{m}^{2} ; n=28, \text { mean BMI } \\
28.1 \mathrm{~kg} / \mathrm{m}^{2} ; n=29 \text {, mean BMI } \\
\left.\quad 34.9 \mathrm{~kg} / \mathrm{m}^{2}\right)\end{array}$ & $\begin{array}{c}\text { FAAH-Pro129Thr SNP } \\
\text { (rs324420) } \\
\text { Genetic association with } \\
\text { gastric emptying (GE) of } \\
\text { solids and liquids, gastric } \\
\text { volume (GV), and satiation } \\
\text { [maximum tolerated volume } \\
\text { (MTV) after nutrient drink } \\
\text { test] }\end{array}$ & $\begin{array}{l}\text { No significant association with GE of solids } \\
\text { or liquids, GV, or aggregate symptom score } \\
\text { Significant association with MTV: lower } \\
\text { MTV in the CC genotype vs. CA/AA }\end{array}$ \\
\hline
\end{tabular}


Table 3. Cont.

\begin{tabular}{|c|c|c|c|}
\hline Reference & Sample & $\begin{array}{l}\text { Gene(s) and Variant(s) and } \\
\text { Study Design }\end{array}$ & Key Findings \\
\hline $\begin{array}{l}\text { Yagin et al. } \\
\text { (2019) [60] }\end{array}$ & $\begin{array}{c}n=180 \text { healthy } \\
\text { overweight } / \text { obese women } \\
\left(\mathrm{BMI}=25-40 \mathrm{~kg} / \mathrm{m}^{2}\right) \\
n=86 \text { women with } \\
\mathrm{BMI}=18.5-24.9 \mathrm{~kg} / \mathrm{m}^{2}\end{array}$ & $\begin{array}{l}\text { FAAH-Pro129Thr SNP } \\
\text { (rs324420) } \\
\text { Case-control genetic } \\
\text { association }\end{array}$ & $\begin{array}{c}\text { A/A and C/A genotypes were more } \\
\text { frequent in overweight/obese women } \\
\text { A-allele carriers had significantly higher } \\
\text { BMI, waist circumference, neck } \\
\text { circumference, waist-to-height ratio, and } \\
\text { body fat mass } \\
\text { A-allele significantly predicted risk of } \\
\text { obesity after adjusting for age, marital } \\
\text { status, and physical activity. (OR: } 2.38 ; 95 \% \\
\text { CI }=1.37-3.79)\end{array}$ \\
\hline $\begin{array}{l}\text { Yagin et al. } \\
(2020)[68]\end{array}$ & $\begin{array}{c}n=180 \text { women (mean BMI } \\
\left.32.54 \mathrm{~kg} / \mathrm{m}^{2}\right)\end{array}$ & $\begin{array}{l}\text { FAAH-Pro129Thr SNP } \\
\text { (rs324420) } \\
\text { Genetic association with binge } \\
\text { eating disorder }\end{array}$ & $\begin{array}{c}\text { No significant association, though the } \\
\text { frequency of the A allele was numerically } \\
\text { higher in women with binge eating } \\
\text { disorder }(p=0.08)\end{array}$ \\
\hline $\begin{array}{l}\text { Zhang et al. } \\
\text { (2009) [61] }\end{array}$ & $\begin{array}{c}n=1644 \text { (from } 261 \text { extended } \\
\text { families) }\end{array}$ & $\begin{array}{c}\text { FAAH-Pro129Thr SNP } \\
\text { (rs324420) and four additional } \\
\text { SNPs (rs324418, rs1984490, } \\
\text { rs2145408 and rs4141964) } \\
\text { Genetic association with } \\
\text { obesity-related traits }\end{array}$ & $\begin{array}{c}\text { A-allele of rs324420 was significantly } \\
\text { associated with higher BMI and fasting } \\
\text { triglyceride levels compared to wildtype } \\
\text { (C/C genotype) }\end{array}$ \\
\hline
\end{tabular}

FAAH, fatty acid amide hydrolase; HOMA, homeostatic model assessment; LDL, low-density lipoprotein; MGLL, monoacylglycerol lipase; SNP, single-nucleotide polymorphism.

\section{Discussion}

The endocannabinoid system plays an important role in the regulation of hunger, satiety, and body weight. Obesity is associated with chronic over-activation of the ECS, with increased levels of circulating endocannabinoids. Thus, modulating the activity of ECS enzymes, thereby altering endocannabinoid signaling, is a biologically plausible strategy for treating obesity. Our review focused on obesity-related outcomes associated with manipulation of or variation in three key enzymes: FAAH, an enzyme responsible for degradation of many bioactive lipids, especially AEA; MAGL, another enzyme responsible for degradation, especially 2-AG; and DAGL, an enzyme involved in the synthesis of 2-AG. We identified 15 studies that involved pharmacological or genetic manipulation of at least one of these enzymes and assessment of at least one obesity-related outcome in an animal model, and 30 studies that examined a genetic association between variants in the genes encoding FAAH and MAGL and obesity in humans. Overall, we found strong evidence that modulating ECS enzyme activity can impact obesity-related outcomes, but the nature of the association is complex and likely dependent on numerous factors, such as species, age, sex, diet, and physical activity.

The preclinical studies reviewed found that either pharmacological inhibition or genetic deletion of FAAH produced obesogenic phenotypes, generally increased body weight, and/or worse metabolic outcomes. For example, Faah knockout mice had greater body weight, fat mass, and triglyceride levels compared to wildtype mice, under both a standard and high-fat diet $[31,32]$. It is important to note that there are many substrates of FAAH other than AEA (many of which do not act at CB receptors) and that the functions of FAAH substrates are incredibly diverse. Genetic deletion or pharmacological inhibition of FAAH produces a myriad of behavioural effects in animal models, including modulation of anxiety- and depressive-like behaviours, alterations in gastrointestinal function, decreases in pain response, decreases in inflammation, and modulation of drug-seeking behaviours and withdrawal [8]. As a result, FAAH inhibitors have been investigated in preclinical models of an incredibly wide range of pathological conditions, including pain (e.g., inflammatory, neuropathic, cancer-associated), neurological conditions (e.g., traumatic brain 
injury, epilepsy, movement-related disorders), gastrointestinal disorders, cardiovascular disorders, and psychiatric disorders (including substance use disorders) [21].

Of the human genetic association studies reviewed, most (26/30) focused on the rs324420 SNP of $F A A H$. Despite the initially compelling association between the A allele of this SNP and increased likelihood of being overweight and obese in a large sample of white and Black adults by Sipe and colleagues [57], which was replicated, at least in part, in three more recent studies $[55,58,60]$, multiple studies have failed to find any association between rs324420 genotype and obesity [62-68]. In addition, two studies actually found a significant association between the homozygous major allele genotype $(\mathrm{C} / \mathrm{C})$ and obesity $[53,56]$. Of note, a handful of studies found that carriers of the A allele of rs324420 had greater improvements after either lifestyle (diet and/or exercise) intervention [43,47] or surgical intervention [51]. However, other studies failed to find greater improvement in A allele carriers [63] or found greater improvement associated with the major C/C genotype [44,49].

The effect of genetic manipulation of $M g l l$ appears to be complex, and likely tissuedependent. Preclinical studies found that overexpression of $M g l l$ in forebrain neurons caused a reduction in weight gain and adiposity [35], yet intestinal overexpression of $\mathrm{Mgll}$ actually led to increased weight gain and fat mass [36]. The tissue-specific effects of $\mathrm{Mgll}$ deletion highlight the complexity of ECS control of energy intake and body weight. For example, MAGL is involved in the hydrolysis of triacylglycerols in adipose tissue [73]. Thus, future work should consider tissue-specific manipulation of MAGL on obesity-related outcomes, which may have important implications for therapeutic trials in humans.

Studies examining manipulation of DAGL were scarce. One study found that the DAGL $\alpha$ inhibitor O-7460 significantly decreased body weight in male mice [29], while another found that Dagla knockout mice had reduced body weight, fat mass, and total triglycerides compared to wildtype mice [40]. No human studies were identified that examined associations between DAGLA gene variants and obesity. This very preliminary evidence suggests that reducing biosynthesis of 2-AG could be one strategy to recapitulate the therapeutic effects of $\mathrm{CB} 1$ receptor antagonism, ideally without the serious psychiatric adverse effects as seen with rimonabant. Similarly, it could be worth exploring potential inhibitors of AEA biosynthesis. To date, there is no single enzyme purported to be the single "AEA synthase", though N-acetylphosphatidylethanolamine-hydrolysing phospholipase D (NAPE-PLD) has been proposed as a candidate [8]. Interestingly, deletion of the gene encoding NAPE-PLD in mouse adipocytes induced an obese state characterized by glucose intolerance, adipose tissue inflammation, and altered lipid metabolism [74]. However, NAPE-PLD is involved in the biosynthesis of many other similar lipids, and NAPE-PLD genetic knockout does not consistently lead to a reduction in AEA [8].

While our review considered only candidate gene association studies in humans involving FAAH or MGLL, a brief note on genome-wide association studies (GWAS) of obesity is worthwhile. Small-scale candidate gene associations studies, such as some of the studies reviewed here, have been useful to identify specific monogenic forms of obesity, which are inherited in a Mendelian pattern and are typically rare, severe, with early onset [75]. Such approaches can also be used to identify common variants associated with polygenic (common) obesity. For example, candidate gene association approaches using larger samples were used to identify significant associations of variants in the CB1 receptor gene (CNR1) with obesity outcomes, which has been a reproducible association [76]. However, GWAS approaches using very large population samples are necessary to confirm the association of common variants contributing small effects to obesity [75]. Loos and Yeo (2021) extracted GWAS data from GWASCatalog, spanning from the first obesity GWAS in 2007 to 25 January 2021. A review of these data found no SNPs in FAAH, MGLL, or $D A G L A / D A G L B$ that showed genome-wide significant association $\left(p<5 \times 10^{-8}\right)$ with obesity or related outcomes (also of note, no SNPs in CNR1 either) [75]. This suggests that variation in ECS genes is unlikely to make a major contribution to polygenic obesity, which is in line with the heterogeneity in results of candidate gene association studies (FAAH and obesity outcomes) we reviewed here. 
Following up on the promising findings of preclinical animal studies of FAAH inhibition in multiple disease models, a number of human trials have been conducted or are ongoing to evaluate the potential of FAAH inhibitors across a range of indications [21]. For example, recently completed trials have found a positive signal for the FAAH inhibitor JNJ42165279 in reducing anxiety symptoms in patients with social anxiety disorder [77] and the FAAH inhibitor PF-04457845 in reducing cannabis withdrawal in men with cannabis dependence [78]. A search of ClinicalTrials.gov identified a number of registered ongoing trials of FAAH inhibitors for substance use disorders, Tourette Syndrome, and pain. There have also been MAGL and dual FAAH/MAGL inhibitors developed to be evaluated in controlled trials. While our review has not provided clear evidence that FAAH or MAGL inhibitors would be useful for treating obesity, it will be worth noting whether there are any weight- or obesity-related effects observed in FAAH and/or MAGL inhibitor trials.

One final important consideration is the role of sex in modulating cannabinoid action. A wealth of preclinical data have established that sex significantly impacts the role of cannabinoids in multiple physiological processes, including pain, reward and addiction, and hunger and energy homeostasis $[79,80]$. For example, it has been demonstrated in rodent models that estradiol replacement in ovariectomized females tends to reduce energy intake in response to the CB1 receptor agonist WIN 55,212-2, while testosterone replacement in orchidectomized males tends to increase energy intake, which can be blocked by the CB1 receptor antagonist AM251 [80]. Unfortunately, the majority of the preclinical studies we reviewed conducted experiments in male animals only. Given that estrogens and testosterone may have divergent effects on energy intake (at least in rodents), future studies must consider sex as a biological variable in order to better understand how manipulation of the ECS may impact obesity differently in male and female bodies.

Taken together, the reviewed body of literature provides a mixed picture of whether FAAH, MAGL, or DAGL are likely to be druggable targets for obesity treatment. Studies in rodent models showed that reduction in FAAH activity leads to increased body weight and metabolic function, and while the human genetic association studies found consistent evidence of association between $F A A H$ variants and obesity, the direction of effect was inconsistent. Thus, based on the evidence reviewed, FAAH inhibition is not likely a promising approach for obesity treatment. It will be prudent to monitor changes in body weight in ongoing trials of FAAH inhibitors for other indications. The role of MAGL modulation in obesity-related phenotypes appeared to be tissue dependent, with different effects depending on whether central or peripheral MAGL was targeted. Further research is needed to clarify this association. Based on a handful of animal studies, inhibition of DAGL $\alpha$ may be a promising strategy to treat obesity. This approach is in line with the higher levels of circulating endocannabinoids found in animals and humans with obesity. However, given the complex relationship between ECS activity and obesity, more evidence is needed to characterize the role of DAGL modulation in obesity. Human studies evaluating associations between DAGLA (and possibly also DAGLB) variants and obesity may provide some additional insight into whether modulating 2-AG synthesis impacts obesity-related outcomes.

Author Contributions: Conceptualization, J.M., X.M.M.Z., B.L.F.; methodology, J.M., X.M.M.Z., B.L.F.; data curation and article screening/review, J.M., X.M.M.Z., and Z.B.; writing-original draft preparation, J.M., X.M.M.Z., and Z.B.; writing-review and editing, all authors. All authors have read and agreed to the published version of the manuscript.

Funding: This research received no direct external funding.

Institutional Review Board Statement: Not applicable.

Informed Consent Statement: Not applicable.

Data Availability Statement: Data sharing not applicable.

Acknowledgments: This article was supported by a Mitacs Accelerate Award to BLF in partnership with Canopy Growth Corporation. 
Conflicts of Interest: Bernard Le Foll has obtained funding from Pfizer Inc. (GRAND Awards, including salary support) for investigator-initiated projects. Le Foll has obtained funding from Indivior for a clinical trial sponsored by Indivior. Le Foll has in-kind donations of cannabis products from Aurora Cannabis Enterprises Inc. and study medication donations from Pfizer Inc. (varenicline for smoking cessation) and Bioprojet Pharma. He was also provided a coil for a Transcranial magnetic stimulation (TMS) study from Brainsway. Le Foll has obtained industry funding from Canopy Growth Corporation (through research grants handled by the Centre for Addiction and Mental Health and the University of Toronto), Bioprojet Pharma, Alcohol Countermeasure Systems (ACS), and Alkermes. Lastly, Le Foll has received in kind donations of nabiximols from GW Pharmaceuticals for past studies funded by CIHR and NIH. He has participated in a session of a National Advisory Board Meeting (Emerging Trends BUP-XR) for Indivior Canada and has been consultant for Shinogi. He is supported by $\mathrm{CAMH}$, a clinician-scientist award from the department of Family and Community Medicine of the University of Toronto and a Chair in Addiction Psychiatry from the department of Psychiatry of University of Toronto. Justin Matheson is currently supported by a Mitacs grant obtained by Le Foll in partnership with Canopy.

\section{References}

1. NCD Risk Factor Collaboration (NCD-RisC). Trends in adult body-mass index in 200 countries from 1975 to 2014 : A pooled analysis of 1698 population-based measurement studies with 19.2 million participants. Lancet 2016, 387, 1377-1396. [CrossRef]

2. NCD Risk Factor Collaboration. Worldwide trends in body-mass index, underweight, overweight, and obesity from 1975 to 2016 : A pooled analysis of 2416 population-based measurement studies in 128,9 million children, adolescents, and adults. Lancet 2017, 390, 2627-2642. [CrossRef]

3. Guh, D.P.; Zhang, W.; Bansback, N.; Amarsi, Z.; Birmingham, C.L.; Anis, A.H. The incidence of co-morbidities related to obesity and overweight: A systematic review and meta-analysis. BMC Public Health 2009, 9, 88. [CrossRef]

4. Spieker, E.A.; Pyzocha, N. Economic Impact of Obesity. Prim. Care 2016, 43, 83-95. [CrossRef]

5. Richey, J.M.; Woolcott, O. Re-visiting the Endocannabinoid System and Its Therapeutic Potential in Obesity and Associated Diseases. Curr. Diab. Rep. 2017, 17, 99. [CrossRef] [PubMed]

6. Lu, H.C.; Mackie, K. An Introduction to the Endogenous Cannabinoid System. Biol. Psychiatry 2016, 79, 516-525. [CrossRef]

7. Pamplona, F.A.; Takahashi, R.N. Psychopharmacology of the endocannabinoids: Far beyond anandamide. J. Psychopharmacol. 2012, 26, 7-22. [CrossRef]

8. Gregus, A.M.; Buczynski, M.W. Druggable Targets in Endocannabinoid Signaling. Adv. Exp. Med. Biol. 2020, 1274, 177-201. [CrossRef] [PubMed]

9. Schulz, P.; Hryhorowicz, S.; Rychter, A.M.; Zawada, A.; Słomski, R.; Dobrowolska, A.; Krela-Kaźmierczak, I. What Role Does the Endocannabinoid System Play in the Pathogenesis of Obesity? Nutrients 2021, 13, 373. [CrossRef] [PubMed]

10. Rahmanian, M.; Lotfi Yaghin, N.; Alizadeh, M. Blood Level of 2-arachidonoyl glycerol (2-AG), Neuropeptide Y and Omentin and Their Correlation with Food Habits in Obese Women. Galen. Med. J. 2020, 9, e1721. [CrossRef]

11. Côté, M.; Matias, I.; Lemieux, I.; Petrosino, S.; Alméras, N.; Després, J.P.; Di Marzo, V. Circulating endocannabinoid levels, abdominal adiposity and related cardiometabolic risk factors in obese men. Int. J. Obes. 2007, 31, 692-699. [CrossRef]

12. Matias, I.; Gatta-Cherifi, B.; Tabarin, A.; Clark, S.; Leste-Lasserre, T.; Marsicano, G.; Piazza, P.V.; Cota, D. Endocannabinoids measurement in human saliva as potential biomarker of obesity. PLoS ONE 2012, 7, e42399. [CrossRef]

13. Yagin, N.L.; Hajjarzadeh, S.; Aliasgharzadeh, S.; Aliasgari, F.; Mahdavi, R. The association of dietary patterns with endocannabinoids levels in overweight and obese women. Lipids Health Dis. 2020, 19, 161. [CrossRef]

14. Azar, S.; Sherf-Dagan, S.; Nemirovski, A.; Webb, M.; Raziel, A.; Keidar, A.; Goitein, D.; Sakran, N.; Shibolet, O.; Tam, J.; et al. Circulating Endocannabinoids Are Reduced Following Bariatric Surgery and Associated with Improved Metabolic Homeostasis in Humans. Obes. Surg. 2019, 29, 268-276. [CrossRef]

15. Murphy, T.; Le Foll, B. Targeting the Endocannabinoid CB1 Receptor to Treat Body Weight Disorders: A Preclinical and Clinical Review of the Therapeutic Potential of Past and Present CB1 Drugs. Biomolecules 2020, 10, 855. [CrossRef]

16. Christopoulou, F.D.; Kiortsis, D.N. An overview of the metabolic effects of rimonabant in randomized controlled trials: Potential for other cannabinoid 1 receptor blockers in obesity. J. Clin. Pharm. Ther. 2011, 36, 10-18. [CrossRef] [PubMed]

17. Leite, C.E.; Mocelin, C.A.; Petersen, G.O.; Leal, M.B.; Thiesen, F.V. Rimonabant: An antagonist drug of the endocannabinoid system for the treatment of obesity. Pharmacol. Rep. 2009, 61, 217-224. [CrossRef]

18. Christensen, R.; Kristensen, P.K.; Bartels, E.M.; Bliddal, H.; Astrup, A. Efficacy and safety of the weight-loss drug rimonabant: A meta-analysis of randomised trials. Lancet 2007, 370, 1706-1713. [CrossRef]

19. Moreira, F.A.; Crippa, J.A. The psychiatric side-effects of rimonabant. Braz. J. Psychiatry 2009, 31, 145-153. [CrossRef]

20. Le Foll, B.; Gorelick, D.A.; Goldberg, S.R. The future of endocannabinoid-oriented clinical research after CB1 antagonists. Psychopharmacology 2009, 205, 171-174. [CrossRef]

21. Toczek, M.; Malinowska, B. Enhanced endocannabinoid tone as a potential target of pharmacotherapy. Life Sci. 2018, 204, 20-45. [CrossRef] [PubMed] 
22. Laleh, P.; Yaser, K.; Alireza, O. Oleoylethanolamide: A novel pharmaceutical agent in the management of obesity-an updated review. J. Cell Physiol. 2019, 234, 7893-7902. [CrossRef]

23. Maccarrone, M.; Rossi, S.; Bari, M.; De Chiara, V.; Fezza, F.; Musella, A.; Gasperi, V.; Prosperetti, C.; Bernardi, G.; Finazzi-Agrò, A.; et al. Anandamide inhibits metabolism and physiological actions of 2-arachidonoylglycerol in the striatum. Nat. Neurosci. 2008, 11, 152-159. [CrossRef]

24. Behl, T.; Chadha, S.; Sachdeva, M.; Sehgal, A.; Kumar, A.; Venkatachalam, T.; Hafeez, A.; Aleya, L.; Arora, S.; Batiha, G.E.S.; et al. Understanding the possible role of endocannabinoid system in obesity. Prostaglandins Other Lipid Mediat. 2021, 152, 106520. [CrossRef] [PubMed]

25. de Moura, E.D.M.; Dos Reis, S.A.; da Conceição, L.L.; Sediyama, C.; Pereira, S.S.; de Oliveira, L.L.; Gouveia Pelúzio, M.D.C.; Martinez, J.A.; Milagro, F.I. Diet-induced obesity in animal models: Points to consider and influence on metabolic markers. Diabetol. Metab. Syndr. 2021, 13, 32. [CrossRef] [PubMed]

26. Balsevich, G.; Sticht, M.; Bowles, N.P.; Singh, A.; Lee, T.T.Y.; Li, Z.; Chelikani, P.K.; Lee, F.S.; Borgland, S.L.; Hillard, C.J.; et al. Role for fatty acid amide hydrolase (FAAH) in the leptin-mediated effects on feeding and energy balance. Proc. Natl. Acad. Sci. USA 2018, 115, 7605-7610. [CrossRef] [PubMed]

27. Cifani, C.; Avagliano, C.; Micioni Di Bonaventura, E.; Giusepponi, M.E.; De Caro, C.; Cristiano, C.; La Rana, G.; Botticelli, L.; Romano, A.; Calignano, A.; et al. Modulation of Pain Sensitivity by Chronic Consumption of Highly Palatable Food Followed by Abstinence: Emerging Role of Fatty Acid Amide Hydrolase. Front. Pharmacol. 2020, 11, 266. [CrossRef]

28. Liu, J.; Cinar, R.; Xiong, K.; Godlewski, G.; Jourdan, T.; Lin, Y.; Ntambi, J.M.; Kunos, G. Monounsaturated fatty acids generated via stearoyl CoA desaturase-1 are endogenous inhibitors of fatty acid amide hydrolase. Proc. Natl. Acad. Sci. USA 2013, 110, 18832-18837. [CrossRef]

29. Bisogno, T.; Mahadevan, A.; Coccurello, R.; Chang, J.W.; Allarà, M.; Chen, Y.; Giacovazzo, G.; Lichtman, A.; Cravatt, B.; Moles, A.; et al. A novel fluorophosphonate inhibitor of the biosynthesis of the endocannabinoid 2-arachidonoylglycerol with potential anti-obesity effects. Br. J. Pharmacol. 2013, 169, 784-793. [CrossRef]

30. Palma-Chavez, A.; Konar-Nié, M.; Órdenes, P.; Maurelia, F.; Elizondo-Vega, R.; Oyarce, K.; López, S.; Rojas, J.; Steinberg, X.; García-Robles, M.A.; et al. Glucose Increase DAGL $\alpha$ Levels in Tanycytes and Its Inhibition Alters Orexigenic and Anorexigenic Neuropeptides Expression in Response to Glucose. Front. Endocrinol. 2019, 10, 647. [CrossRef] [PubMed]

31. Touriño, C.; Oveisi, F.; Lockney, J.; Piomelli, D.; Maldonado, R. FAAH deficiency promotes energy storage and enhances the motivation for food. Int. J. Obes. 2010, 34, 557-568. [CrossRef] [PubMed]

32. Vaitheesvaran, B.; Yang, L.; Hartil, K.; Glaser, S.; Yazulla, S.; Bruce, J.E.; Kurland, I.J. Peripheral Effects of FAAH Deficiency on Fuel and Energy Homeostasis: Role of Dysregulated Lysine Acetylation. PLoS ONE 2012, 7, e33717. [CrossRef]

33. Brown, W.H.; Gillum, M.P.; Lee, H.-Y.; Camporez, J.P.G.; Zhang, X.-M.; Jeong, J.K. Fatty acid amide hydrolase ablation promotes ectopic lipid storage and insulin resistance due to centrally mediated hypothyroidism. Proc. Natl. Acad. Sci. USA 2012, 109, 14966-14971. [CrossRef]

34. Grevengoed, T.J.; Trammell, S.A.J.; McKinney, M.K.; Petersen, N.; Cardone, R.L.; Svenningsen, J.S.; Ogasawara, D.; Nexøe-Larsen, C.C.; Knop, F.K.; Schwartz, T.W.; et al. N-acyl taurines are endogenous lipid messengers that improve glucose homeostasis. Proc. Natl. Acad. Sci. USA 2019, 116, 24770-24778. [CrossRef]

35. Jung, K.-M.; Clapper, J.R.; Fu, J.; D'Agostino, G.; Guijarro, A.; Thongkham, D.; Avanesian, A.; Astarita, G.; DiPatrizio, N.V.; Frontini, A.; et al. 2-Arachidonoylglycerol Signaling in Forebrain Regulates Systemic Energy Metabolism. Cell Metab. 2012, 15, 299-310. [CrossRef]

36. Chon, S.-H.; Douglass, J.D.; Zhou, Y.X.; Malik, N.; Dixon, J.L.; Brinker, A.; Quadro, L.; Storch, J. Over-Expression of Monoacylglycerol Lipase (MGL) in Small Intestine Alters Endocannabinoid Levels and Whole Body Energy Balance, Resulting in Obesity. PLoS ONE 2012, 7, e43962. [CrossRef]

37. Tardelli, M.; Bruschi, F.V.; Claudel, T.; Fuchs, C.D.; Auer, N.; Kunczer, V.; Stojakovic, T.; Scharnagl, H.; Habib, A.; Grabner, G.F.; et al. Lack of monoacylglycerol lipase prevents hepatic steatosis by favoring lipid storage in adipose tissue and intestinal malabsorption. J. Lipid Res. 2019, 60, 1284-1292. [CrossRef]

38. Yoshida, K.; Kita, Y.; Tokuoka, S.M.; Hamano, F.; Yamazaki, M.; Sakimura, K.; Kano, M.; Shimizu, T. Monoacylglycerol lipase deficiency affects diet-induced obesity, fat absorption, and feeding behavior in CB1 cannabinoid receptor-deficient mice. FASEB J. 2019, 33, 2484-2497. [CrossRef] [PubMed]

39. Douglass, J.D.; Zhou, Y.X.; Wu, A.; Zadrogra, J.A.; Gajda, A.M.; Lackey, A.I.; Lang, W.; Chevalier, K.M.; Sutton, S.W.; Zhang, S.P.; et al. Global deletion of MGL in mice delays lipid absorption and alters energy homeostasis and diet-induced obesity. J. Lipid Res. 2015, 56, 1153-1171. [CrossRef]

40. Powell, D.R.; Gay, J.P.; Wilganowski, N.; Doree, D.; Savelieva, K.V.; Lanthorn, T.H.; Read, R.; Vogel, P.; Hansen, G.M.; Brommage, R.; et al. Diacylglycerol Lipase $\alpha$ Knockout Mice Demonstrate Metabolic and Behavioral Phenotypes Similar to Those of Cannabinoid Receptor 1 Knockout Mice. Front. Endocrinol. 2015, 6, 86. [CrossRef] [PubMed]

41. Sipe, J.C.; Chiang, K.; Gerber, A.L.; Beutler, E.; Cravatt, B.F. A missense mutation in human fatty acid amide hydrolase associated with problem drug use. Proc. Natl. Acad. Sci. USA 2002, 99, 8394-8399. [CrossRef]

42. Chiang, K.P.; Gerber, A.L.; Sipe, J.C.; Cravatt, B.F. Reduced cellular expression and activity of the P129T mutant of human fatty acid amide hydrolase: Evidence for a link between defects in the endocannabinoid system and problem drug use. Hum. Mol. Genet. 2004, 13, 2113-2119. [CrossRef] 
43. Aberle, J.; Fedderwitz, I.; Klages, N.; George, E.; Beil, F.U. Genetic Variation in Two Proteins of the Endocannabinoid System and their Influence on Body Mass Index and Metabolism under Low Fat Diet. Horm. Metab. Res. 2007, 39, 395-397. [CrossRef]

44. de Luis, D.; Aller, R.; Izaola, O.; Conde, R.; de la Fuente, B.; Sagrado, M.G. Genetic variation in the endocannabinoid degrading enzyme fatty acid amide hydrolase (FAAH) and their influence on weight loss and insulin resistance under a high monounsaturated fat hypocaloric diet. J. Diabetes Complicat. 2013, 27, 235-239. [CrossRef] [PubMed]

45. de Luis, D.A.; Aller, R.; Izaola, O.; Conde, R.; Sagrado, M.G.; Primo, D.; Castro, M.J. Relationship among metabolic syndrome, C358A polymorphism of the endocannabinoid degrading enzyme fatty acid amide hydrolase (FAAH) and insulin resistance. J. Diabetes Complicat. 2012, 26, 328-332. [CrossRef]

46. de Luis, D.A.; González Sagrado, M.; Aller, R.; Izaola, O.; Conde, R. Relation of C358A polymorphism of the endocannabinoid degrading enzyme fatty acid amide hydrolase (FAAH) with obesity and insulin resistance. Nutr. Hosp. 2010, 25, 993-998. [PubMed]

47. de Luis, D.A.; Gonzalez Sagrado, M.; Aller, R.; Izaola, O.; Conde, R. Effects of C358A missense polymorphism of the endocannabinoid degrading enzyme fatty acid amide hydrolase on weight loss after a hypocaloric diet. Metab. Clin. Exp. 2011, 60, 730-734. [CrossRef] [PubMed]

48. de Luis, D.A.; Gonzalez Sagrado, M.; Aller, R.; Izaola, O.; Conde, R.; Romero, E. C358A missense polymorphism of the endocannabinoid-degrading enzyme fatty acid amide hydrolase (FAAH) and visfatin levels in obese females. Int. J. Obes. 2010, 34, 511-515. [CrossRef] [PubMed]

49. de Luis, D.A.; Izaola, O.; Aller, R.; de La Fuente, B.; Pacheco, D. Effects of C358A polymorphism of the endocannabinoid degrading enzyme fatty acid amide hydrolase (FAAH) on weight loss, adipocytokines levels, and insulin resistance after a high polyunsaturated fat diet in obese patients. J. Endocrinol. Investig. 2013, 36, 965-969. [CrossRef]

50. de Luis, D.A.; Sagrado, M.G.; Aller, R.; Izaola, O.; Conde, R.; Romero, E. C358A missense polymorphism of the endocannabinoid degrading enzyme fatty acid amide hydrolase (FAAH) and insulin resistance in patients with diabetes mellitus type 2 . Diabetes Res. Clin. Pract. 2010, 88, 76-80. [CrossRef]

51. de Luis, D.A.; Sagrado, M.G.; Pacheco, D.; Terroba, M.C.; Martin, T.; Cuellar, L.; Ventosa, M. Effects of C358A missense polymorphism of the endocannabinoid degrading enzyme fatty acid amide hydrolase on weight loss and cardiovascular risk factors 1 year after biliopancreatic diversion surgery. Surg. Obes. Relat. Dis. 2010, 6, 516-520. [CrossRef]

52. de Luis, D.A.; Sagrado, M.G.; Aller, R.; Izaola, O.; Conde, R. Effects of C358A missense polymorphism of the degrading enzyme fatty acid amide hydrolase on weight loss, adipocytokines, and insulin resistance after 2 hypocaloric diets. Metab. Clin. Exp. 2010, 59, 1387-1392. [CrossRef]

53. Durand, E.; Lecoeur, C.; Delplanque, J.; Benzinou, M.; Degraeve, F.; Boutin, P.; Marre, M.; Balkau, B.; Charpentier, G.; Froguel, P.; et al. Evaluating the Association of FAAH Common Gene Variation with Childhood, Adult Severe Obesity and Type 2 Diabetes in the French Population. Obes. Facts 2008, 1, 305-309. [CrossRef]

54. Grolmusz, V.K.; Stenczer, B.; Fekete, T.; Szendei, G.; Patócs, A.; Rácz, K.; Reismann, P. Lack of Association between C385A Functional Polymorphism of the Fatty Acid Amide Hydrolase Gene and Polycystic Ovary Syndrome. Exp. Clin. Endocrinol. Diabetes 2013, 121, 338-342. [CrossRef]

55. Monteleone, P.; Tortorella, A.; Martiadis, V.; Di Filippo, C.; Canestrelli, B.; Maj, M. The cDNA 385C to A missense polymorphism of the endocannabinoid degrading enzyme fatty acid amide hydrolase (FAAH) is associated with overweight/obesity but not with binge eating disorder in overweight/obese women. Psychoneuroendocrinology 2008, 33, 546-550. [CrossRef] [PubMed]

56. Müller, T.D.; Brönner, G.; Wandolski, M.; Carrie, J.; Nguyen, T.T.; Greene, B.H.; Scherag, A.; Grallert, H.; Vogel, C.I.; Scherag, S.; et al. Mutation screen and association studies for the fatty acid amide hydrolase (FAAH) gene and early onset and adult obesity. BMC Med. Genet. 2010, 11, 2. [CrossRef]

57. Sipe, J.C.; Waalen, J.; Gerber, A.; Beutler, E. Overweight and obesity associated with a missense polymorphism in fatty acid amide hydrolase (FAAH). Int. J. Obes. 2005, 29, 755-759. [CrossRef] [PubMed]

58. Thethi, T.K.; Sigel, A.; Japa, S.; Katalenich, B.; Liu, S.; Nguyen, T.; Larrazolo, J.; Syu, S.; Carefoot, E.; McDuffie, R.; et al. Racial and sex differences in the polymorphisms of the endocannabinoid receptor genes in obesity. J. Diabetes Complicat. 2020, $34,107682$. [CrossRef]

59. Vazquez-Roque, M.I.; Camilleri, M.; Vella, A.; Carlson, P.; Laugen, J.; Zinsmeister, A.R. Association of genetic variation in cannabinoid mechanisms and gastric motor functions and satiation in overweight and obesity. Neurogastroenterol. Motil. 2011, 23, 637-e257. [CrossRef]

60. Yagin, N.L.; Aliasgari, F.; Aliasgharzadeh, S.; Mahdavi, R.; Akbarzadeh, M. The influence of the fatty acid amide hydrolase 385C $>$ A single nucleotide polymorphisms on obesity susceptibility. Mol. Biol. Rep. 2019, 46, 5049-5055. [CrossRef]

61. Zhang, Y.; Sonnenberg, G.E.; Baye, T.M.; Littrell, J.; Gunnell, J.; DeLaForest, A.; MacKinney, E.; Hillard, C.J.; Kissebah, A.H.; Olivier, M.; et al. Obesity-related dyslipidemia associated with FAAH, independent of insulin response, in multigenerational families of Northern European descent. Pharmacogenomics 2009, 10, 1929-1939. [CrossRef]

62. Jensen, D.P.; Andreasen, C.H.; Andersen, M.K.; Hansen, L.; Eiberg, H.; Borch-Johnsen, K.; Jørgensen, T.; Hansen, T.; Pedersen, O. The functional Pro129Thr variant of the FAAH gene is not associated with various fat accumulation phenotypes in a populationbased cohort of 5801 whites. J. Mol. Med. 2007, 85, 445-449. [CrossRef] 
63. Knoll, N.; Volckmar, A.L.; Pütter, C.; Scherag, A.; Kleber, M.; Hebebrand, J.; Hinney, A.; Reinehr, T. The Fatty Acid Amide Hydrolase (FAAH) Gene Variant rs324420 AA/AC is not Associated with Weight Loss in a 1-Year Lifestyle Intervention for Obese Children and Adolescents. Horm. Metab. Res. 2012, 44, 75-77. [CrossRef]

64. Lieb, W.; Manning, A.K.; Florez, J.C.; Dupuis, J.; Cupples, L.A.; McAteer, J.B.; Vasan, R.S.; Hoffmann, U.; O’Donnell, C.J.; Meigs, J.B.; et al. Variants in the CNR1 and the FAAH Genes and Adiposity Traits in the Community. Obesity 2009, 17, 755-760. [CrossRef] [PubMed]

65. Mansouri, E.; Nobrega, J.N.; Hill, M.N.; Tyndale, R.F.; Lee, F.S.; Hendershot, C.S.; Best, L.M.; Di Ciano, P.; Balsevich, G.; Sloan, M.E.; et al. D3 dopamine receptors and a missense mutation of fatty acid amide hydrolase linked in mouse and men: Implication for addiction. Neuropsychopharmacology 2020, 45, 745-752. [CrossRef] [PubMed]

66. Martins, C.J.D.M.; Genelhu, V.; Pimentel, M.M.G.; Celoria, B.M.J.; Mangia, R.F.; Aveta, T.; Silvestri, C.; Di Marzo, V.; Francischetti, E.A. Circulating Endocannabinoids and the Polymorphism 385C >A in Fatty Acid Amide Hydrolase (FAAH) Gene May Identify the Obesity Phenotype Related to Cardiometabolic Risk: A Study Conducted in a Brazilian Population of Complex Interethnic Admixture. PLoS ONE 2015, 10, e0142728. [CrossRef]

67. Papazoglou, D.; Panagopoulos, I.; Papanas, N.; Gioka, T.; Papadopoulos, T.; Papathanasiou, P.; Kaitozis, O.; Papatheodorou, K.; Maltezos, E. The Fatty Acid Amide Hydrolase (FAAH) Pro129Thr Polymorphism is not Associated with Severe Obesity in Greek Subjects. Horm. Metab. Res. 2008, 40, 907-910. [CrossRef]

68. Yagin, N.L.; Aliasgari, F.; Alizadeh, M.; Aliasgharzadeh, S.; Mahdavi, R. Comparison of endocannabinoids levels, FAAH gene polymorphisms, and appetite regulatory substances in women with and without binge eating disorder: A cross-Sectional study. Nutr. Res. 2020, 83, 86-93. [CrossRef]

69. Bhatia, G.; Bansal, V.; Harismendy, O.; Schork, N.J.; Topol, E.J.; Frazer, K.; Bafna, V. A Covering Method for Detecting Genetic Associations between Rare Variants and Common Phenotypes. PLOS Comput. Biol. 2010, 6, e1000954. [CrossRef] [PubMed]

70. Harismendy, O.; Bansal, V.; Bhatia, G.; Nakano, M.; Scott, M.; Wang, X.; Dib, C.; Turlotte, E.; Sipe, J.C.; Murray, S.S.; et al. Population sequencing of two endocannabinoid metabolic genes identifies rare and common regulatory variants associated with extreme obesity and metabolite level. Genome Biol. 2010, 11, R118. [CrossRef]

71. Kuk, A.Y.C.; Li, X.; Xu, J. A fast collapsed data method for estimating haplotype frequencies from pooled genotype data with applications to the study of rare variants. Stat. Med. 2013, 32, 1343-1360. [CrossRef]

72. Ning, T.; Zou, Y.; Yang, M.; Lu, Q.; Chen, M.; Liu, W.; Zhao, S.; Sun, Y.; Shi, J.; Ma, Q.; et al. Genetic interaction of DGAT2 and FAAH in the development of human obesity. Endocrine 2017, 56, 366-378. [CrossRef]

73. Fredrikson, G.; Tornqvist, H.; Belfrage, P. Hormone-sensitive lipase and monoacylglycerol lipase are both required for complete degradation of adipocyte triacylglycerol. Biochim. Biophys. Acta 1986, 876, 288-293. [CrossRef]

74. Geurts, L.; Everard, A.; Van Hul, M.; Essaghir, A.; Duparc, T.; Matamoros, S.; Plovier, H.; Castel, J.; Denis, R.G.; Bergiers, M. Adipose tissue NAPE-PLD controls fat mass development by altering the browning process and gut microbiota. Nat. Commun. 2015, 6, 6495. [CrossRef]

75. Loos, R.J.F.; Yeo, G.S.H. The genetics of obesity: From discovery to biology. Nat. Rev. Genet. 2021, 1-14. [CrossRef]

76. Benzinou, M.; Chèvre, J.C.; Ward, K.J.; Lecoeur, C.; Dina, C.; Lobbens, S.; Durand, E.; Delplanque, J.; Horber, F.F.; Heude, B.; et al. Endocannabinoid receptor 1 gene variations increase risk for obesity and modulate body mass index in European populations. Hum. Mol. Genet. 2008, 17, 1916-1921. [CrossRef]

77. Schmidt, M.E.; Liebowitz, M.R.; Stein, M.B.; Grunfeld, J.; Van Hove, I.; Simmons, W.K.; Van Der Ark, P.; Palmer, J.A.; Saad, Z.S.; Pemberton, D.J.; et al. The effects of inhibition of fatty acid amide hydrolase (FAAH) by JNJ-42165279 in social anxiety disorder: A double-blind, randomized, placebo-controlled proof-of-concept study. Neuropsychopharmacology 2021, 46, 1004-1010. [CrossRef]

78. D'Souza, D.C.; Cortes-Briones, J.; Creatura, G.; Bluez, G.; Thurnauer, H.; Deaso, E.; Bielen, K.; Surti, T.; Radhakrishnan, R.; Gupta, A.; et al. Efficacy and safety of a fatty acid amide hydrolase inhibitor (PF-04457845) in the treatment of cannabis withdrawal and dependence in men: A double-blind, placebo-controlled, parallel group, phase 2a single-site randomised controlled trial. Lancet Psychiatry 2019, 6, 35-45. [CrossRef]

79. Cooper, Z.D.; Craft, R.M. Sex-Dependent Effects of Cannabis and Cannabinoids: A Translational Perspective. Neuropsychopharmacology 2018, 43, 34-51. [CrossRef]

80. Wagner, E.J. Sex differences in cannabinoid-regulated biology: A focus on energy homeostasis. Front. Neuroendocrinol. 2016, 40, 101-109. [CrossRef] [PubMed] 